\title{
Unaccounted role of Mediterranean Water in the drawdown of anthropogenic carbon
}

\author{
Marta Álvarez and Fiz F. Pérez \\ Instituto de Investigaciones Marinas, Vigo, Spain \\ Deborah R. Shoosmith \\ Rosenstiel School of Marine and Atmospheric Science, University of Miami, Miami, Florida, USA
}

Harry L. Bryden

Southampton Oceanography Centre, Southampton, UK

Received 29 July 2004; revised 16 March 2005; accepted 19 May 2005; published 14 September 2005.

[1] A three-sided box, MedBox, comprising the Strait of Gibraltar, $24^{\circ}-41^{\circ} \mathrm{N}$ east of $22^{\circ} \mathrm{W}$, was constructed using hydrographic and chemical data from three World Ocean Circulation Experiment cruises in 1997-1998. An extended optimum multiparameter (OMP) analysis resolves the water mass structure in the MedBox. The mass transport is estimated from data and models warranting mass conservation and no deep water formation within the region. Combining the mass transport, the OMP analysis, and the spatial distribution of anthropogenic carbon $\left(\mathrm{C}_{\mathrm{ANT}}\right)$, some relevant questions about the Mediterranean Water (MW) formation, transport, and role in the global $\mathrm{CO}_{2}$ cycle are resolved. MW is produced at a rate of $2.7 \pm 0.2 \mathrm{~Sv}$ in the eastern North Atlantic. It entrains $2.3 \mathrm{~Sv}$ of central waters during its formation, including also remnants of Antarctic Intermediate Water. The main advection route of MW is northward, close to the Iberian margin $(2.2 \mathrm{~Sv})$, while about $0.5 \mathrm{~Sv}$ are exported into the subtropical eastern North Atlantic. The eastern North Atlantic within the MedBox is a strong region of air-sea $\mathrm{C}_{\mathrm{ANT}}$ uptake, $0.7 \pm 0.7 \mathrm{mmol} \mathrm{m} \mathrm{m}^{-2} \mathrm{~d}^{-1}$, where $\mathrm{C}_{\mathrm{ANT}}$ is accumulated at a rate of $66 \pm 21 \mathrm{kmol} \mathrm{s}^{-1}$

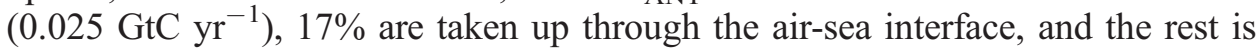
advected into the area by the circulation. The entrainment of central waters to form MW drives a drawdown of $151 \pm 14 \mathrm{kmol} \mathrm{s}^{-1}\left(0.06 \mathrm{GtC} \mathrm{yr}^{-1}\right)$ from the surface to intermediate levels, and $88 \pm 8 \mathrm{kmol} \mathrm{s}^{-1}\left(0.03 \mathrm{GtC} \mathrm{yr}^{-1}\right)$ are exported with MW into the North Atlantic, mainly by the horizontal/eddy circulation.

Citation: Álvarez, M., F. F. Pérez, D. R. Shoosmith, and H. L. Bryden (2005), Unaccounted role of Mediterranean Water in the drawdown of anthropogenic carbon, J. Geophys. Res., 110, C09S03, doi:10.1029/2004JC002633.

\section{Introduction}

[2] The eastern North Atlantic is a region of eastern boundary ventilation, where the transition from southern to northern Atlantic central waters occurs, it is also the source region of Mediterranean Water and constitutes a coastal upwelling region favorable for primary production and air-sea $\mathrm{CO}_{2}$ exchange.

[3] The term "eastern boundary ventilation" refers to the mechanism by which surface water having entered a boundary layer is vertically mixed and reinjected into the ocean interior at deeper levels [Arhan et al., 1994, and references therein]. The entrainment of central waters to depth when Mediterranean Water (MW) spills out of the Strait of Gibraltar is one of the main forms of eastern boundary ventilation. MW plays an indirect but key role in

Copyright 2005 by the American Geophysical Union. 0148-0227/05/2004JC002633 the North Atlantic circulation [Reid, 1979; McCartney and Mauritzen, 2001] and consequently in the thermohaline circulation on timescales of global climate change [ $\mathrm{Wu}$ and Haines, 1996].

[4] This study gives insights into the circulation of water masses in the eastern North Atlantic and the role of this region in the $\mathrm{CO}_{2}$ ocean budget. Mass transports across the edges of a box enclosing the Strait of Gibraltar combined with a mixing analysis and $\mathrm{CO}_{2}$ data will enable us to quantify the contribution of the different water masses to the eastern North Atlantic circulation and the $\mathrm{CO}_{2}$ transport. Particular questions to be answered are how much and where is MW transported into the eastern North Atlantic and how much anthropogenic carbon is drawn down when MW is formed.

[5] This study extends those by Slater [2003] and D. R. Shoosmith and H. L. Bryden (Transport of Mediterranean Water in the North Atlantic Ocean: A hydrographic study, submitted to Journal of Geophysical Research, 2005, here- 


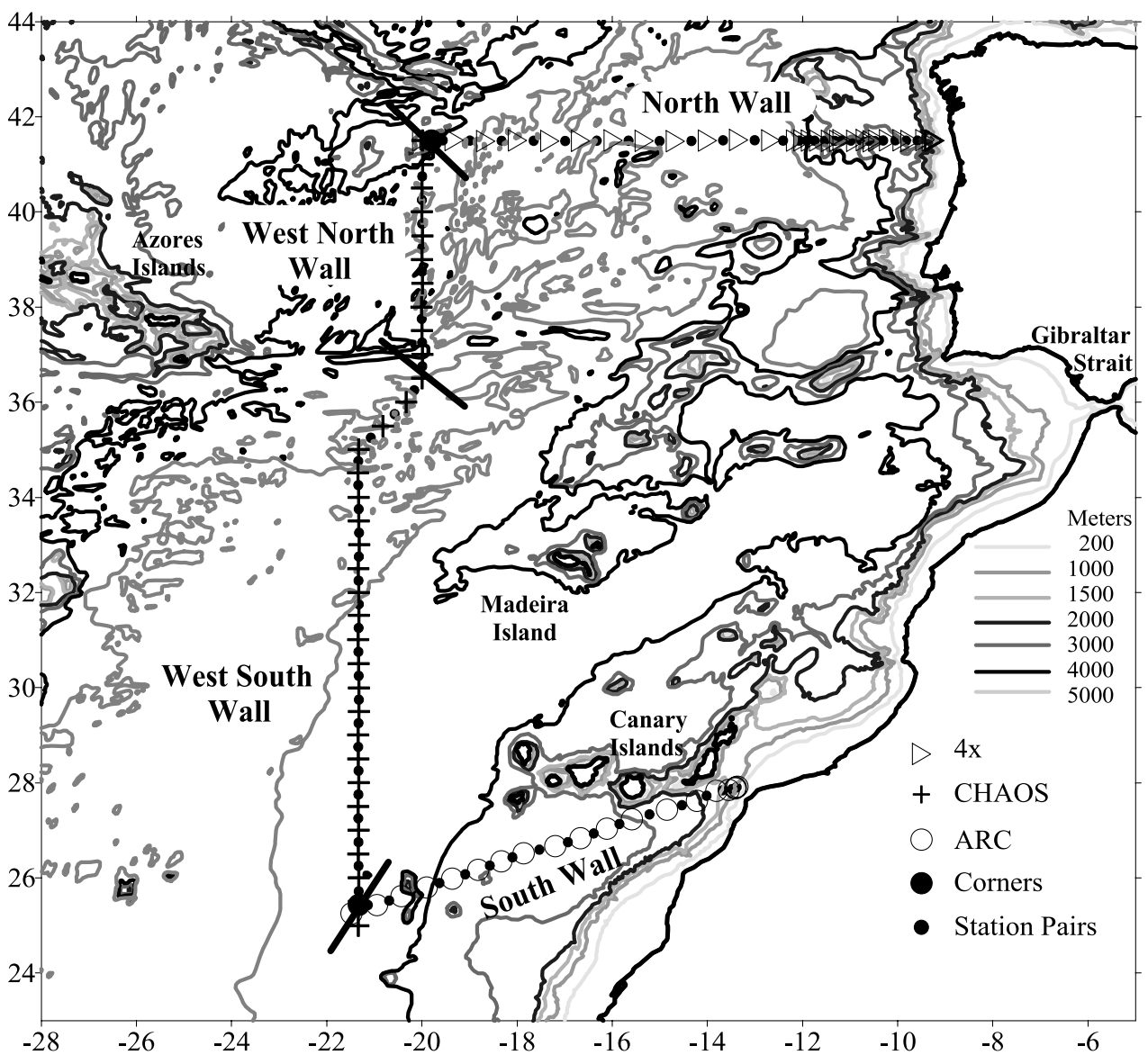

Figure 1. Station locations for the sections used in defining MedBox 98. The location of the station pairs and corner stations are also shown. The MedBox is separated into north, west north, west south, and south walls, and the corresponding limits are indicated by bold diagonal or horizontal black lines.

inafter referred to as $\mathrm{S} \& \mathrm{~B}$ ) focused on the temporal quantification of MW transport in the North Atlantic from hydrographic data.

\section{Data Set}

[6] A three sided box was created around the Strait of Gibraltar encompassing the Mediterranean Outflow (Figure 1). Hydrographic and chemical data from three World Ocean Circulation Experiment (WOCE) cruises undertaken in 1997 and 1998 were taken to create the named MedBox 98 (see Table 1). In this study, hydrographic conductivity-temperature-depth (CTD) data along with oxygen, nutrients and $\mathrm{CO}_{2}$ bottle data $(\mathrm{pH}$, alkalinity and total inorganic carbon in the ARC section and just $\mathrm{pH}$ and alkalinity in the other ones) will be used. Details about the analysis methodology and quality control are given in the corresponding cruise report and related works (Table 1).

[7] As described by S\&B and Slater [2003] the 2 dbar hydrographic CTD data were gridded onto a constant pressure interval grid, from 10 to $5500 \mathrm{dbar}$, every $20 \mathrm{dbar}$. Accordingly, chemical data from bottle depths were linearly interpolated to match the physical field. From the perspective of the MedBox, the data has been gridded in such a way that positive velocities denote transport into the MedBox.
[8] Although measurements were done following WOCE standards, when joining data sets from different sources there could be offsets in the measurements due to changes in the water column structure and systematic sampling and/or analytical errors. S\&B detected and corrected systematic differences in the salinity measurements between the three MedBox cruises checking the internal consistency of the data below 3000 dbar, characterized by very homogeneous thermohaline properties. The internal consistency of the chemical data for nutrients, oxygen and $\mathrm{CO}_{2}$ was also carefully checked studying the residuals from the mixing analysis (see next section) in deep waters below $3000 \mathrm{dbar}$.

[9] Anthropogenic carbon $\left(\mathrm{C}_{\mathrm{ANT}}\right)$ was calculated following the Gruber et al. [1996] methodology along with the improvements suggested by Pérez et al. [2002] for the North Atlantic.

[10] The MedBox was divided into four sections in order to more easily describe the results. The ARC portion is our southern wall, the CHAOS portion is divided into two, west north and west south walls, the $4 \mathrm{x}$ portion is our northern wall (Figure 1).

\section{Methods}

[11] A mixing analysis is used to decompose each sample into the contribution of different source water masses in the 
Table 1. Cruise Data Used for the MedBox 98

\begin{tabular}{llccc}
\hline Cruise Name $($ Latitude) & Ship (Cruise Number) & Cruise Dates & Stations Used & References \\
\hline ARC $\left(\sim 24.5^{\circ} \mathrm{N}\right)$ & R/V Ronald H. Brown & Jan-Feb 1998 & $1-18$ & Baringer and Molinari [1999], Macdonald et al. \\
& & & [2003], Peltola et al. [2001] \\
CHAOS $\left(\sim 20^{\circ} \mathrm{W}\right)$ & RRS Discovery $(233)$ & May-Jun 1998 & $\begin{array}{c}13,428-13,458 \\
\text { Aug } 1997\end{array}$ & $\begin{array}{c}\text { Smythe-Wright [1999], Soler-Aristegui [2002] } \\
\text { Álvarez et al. [2003], Bacon [1998], Bacon et al. } \\
\text { [2002] }\end{array}$ \\
\hline
\end{tabular}

eastern North Atlantic. Another crucial step in this work is the estimation of the velocity field to calculate the mass and biogeochemical transports. Combining the mixing analysis with the mass transport, we can estimate the contribution of each water mass to the mass and biogeochemical transports into or out of the MedBox as by Álvarez et al. [2004]. A sensitivity analysis is performed to estimate the effect of water mass variations over their distributions and transports. Here we finally define the methodology used to decompose the mass and $\mathrm{C}_{\mathrm{ANT}}$ transports into their components.

\subsection{Mixing Analysis}

[12] The water mass structure along the MedBox is resolved by means of an extended optimum multiparameter (OMP) approach [e.g., Karstensen and Tomczak, 1998; Alvarez et al., 2004]. Briefly, the OMP method consists of quantifying the mixture of a set of source water types (SWT) that makes up a given water parcel/sample. The mixing is solved by minimizing the residuals of a set of tracer linear mixing equations for conservative and nonconservative variables in a nonnegative least squares (NNLS) sense, where mass is stringently conserved and the contributions of the different SWT must be positive.

[13] In this analysis, we have used as conservative parameters potential temperature $(\theta)$, salinity $(S)$ and assumed the conservative behavior of silicate $\left(\mathrm{SiO}_{4}\right)$. The nonconservative tracers used were nitrate $\left(\mathrm{NO}_{3}\right)$, phosphate $\left(\mathrm{PO}_{4}\right)$ and oxygen $\left(\mathrm{O}_{2}\right)$. Biological processes are modeled using oxygen, so that oxygen consumption from the initial close to saturation conditions is converted to nitrate and phosphate units using the Redfield ratios by Fraga et al. [1998]. The selection of the SWT and their mixing criteria are critical steps in the OMP definition, reasonable results are only obtained if realistic end-members are mixed in agreement with the knowledge about water mass distribution and circulation within the region.

[14] Upper waters in the eastern North Atlantic comprise two mode waters, subtropical and subpolar Eastern North Atlantic Central Water (ENACW) [Harvey, 1981; Ríos et al., 1992; Pollard et al., 1996]. The mode water formed near the Madeira Island [Siedler et al., 1987] is modeled by the Madeira Mode Water (MMW) extreme and the upper limit of subtropical ENACW $\left(\mathrm{ENACW}_{T}\right)$. The later of these and the extreme named $H$ in honor of Harvey enclose subtropical ENACW. Subpolar ENACW is comprised between $H$ and its lower limit (ENACWp). See Table 2 for the SWT characteristics. Antarctic Intermediate Water (AAIW) is formed north of the subantarctic front and east of the Drake Passage [McCartney, 1977, 1982; Reid, 1994], it extends along the South Atlantic until about $20^{\circ} \mathrm{N}$ and further north within the Gulf Stream North Atlantic Current system [Tsuchiya, 1989]. In this study we refer to the diluted
AAIW (about $11 \%$ of pure AAIW) encountered in the North Atlantic as AA with the $\theta-S$ characteristics of $7.5^{\circ} \mathrm{C}$ and 35 in agreement with former studies in the area [Fraga et al., 1985; Tsuchiya et al., 1992; Pérez et al., 2001].

[15] The intermediate waters encountered are MW and Labrador Sea Water (LSW) defined as in Table 2 and widely known by the oceanographic community. See Table 2 and the references of Alvarez et al. [2004] for an overview.

[16] The deep water in the region is North Eastern Atlantic Deep Water (NEADW), which is warmed Antarctic Bottom Water entering the eastern North Atlantic at the Vema Fracture Zone [Saunders, 1987; McCartney et al., 1991]. In the Iberian Basin below 2500 dbar, NEADW is quite homogeneous in its thermohaline characteristics with a linear trend in the $\theta-S$ representation [Saunders, 1986; Mantyla, 1994]. For NEADW in the Iberian Basin, we selected the $\theta-S$ values given by Castro et al. [1998] for the upper and lower limits (Table 2). However, we actually decomposed the upper NEADW into its components; LSW, lower NEADW or Lower Deep Water (LDW) and IcelandScotland Overflow Water (ISOW) in order to more simply describe the transport results.

[17] Biogeochemical data in the source regions were initially extrapolated from regression lines with salinity and temperature as by Poole and Tomczak [1999], then an iterative process was done [Álvarez et al., 2004] to refine these estimations. Note that biogeochemical properties in Table 2 represent preformed values, oxygen is close to saturation and nutrient values are low.

[18] Within the OMP analysis each tracer equation is properly weighted, tracers more accurately measured have a higher weight in resolving the system (Table 2). Each weight is calculated dividing the standard deviation of the tracer in the SWT matrix and the sum of the analytical error plus the maximum error ascribed to the estimation of the SWT tracers. A weight of 100 has been attributed to the mass conservation equation, which is thus always accurately conserved.

[19] The total number of unknowns is 11,10 SWT contributions and the biological activity introduced as a function of oxygen. On the other hand the number of tracers used in the mixing analysis is six (Table 2). Therefore only a maximum of seven SWT can be simultaneously considered. In order to solve this problem we propose several oceanographic criteria, using mixing spaces coherent with the water mass dynamics within the region. Upper waters are resolved with the following mixing spaces: $\mathrm{MMW}_{\mathrm{ENACW}}, \mathrm{ENACW}_{T}-H$. Intermediate waters by $H$-ENACW $p$-AA-MW, ENACW $p$-AA-MW-LSW and ENACW $p$-MW-LSW-NEADW $u$. Deep waters by AA-MW-LSW-NEADW $u$, AA-MW-LSW-NEADW $l$ and MW-LSW-ISOW-NEADW $l$. AA is only allowed for lati- 
Table 2. Characteristics, Errors, and Weights (W) of the Source Water Types (SWT) ${ }^{\mathrm{a}}$

\begin{tabular}{|c|c|c|c|c|c|c|c|c|}
\hline SWT & $\begin{array}{l}\theta, \\
{ }^{\circ} \mathrm{C} \\
\end{array}$ & $\begin{array}{c}\text { Salinity, } \\
\text { psu }\end{array}$ & $\begin{array}{c}\mathrm{SiO}_{4} \\
\mu \mathrm{mol} \mathrm{kg} \\
\end{array}$ & $\begin{array}{c}\mathrm{NO}_{3}, \\
\mu \mathrm{mol} \mathrm{kg} \\
\end{array}$ & $\begin{array}{c}\mathrm{PO}_{4} \\
\mu \mathrm{mol} \mathrm{kg} \\
\end{array}$ & $\begin{array}{c}\text { TA, } \\
\mu \mathrm{mol} \mathrm{kg} \\
\end{array}$ & $\begin{array}{c}\mathrm{O}_{2} \\
\mu \mathrm{mol} \mathrm{kg} \\
\end{array}$ & $\begin{array}{c}\text { TIC, } \\
\mu \mathrm{mol} \mathrm{kg}{ }^{-1} \\
\end{array}$ \\
\hline MMW & $20.00 \pm 0.5$ & $37.00 \pm 0.04$ & $0.39 \pm 0.3$ & $0.23 \pm 0.01$ & $0.01 \pm 0.06$ & $2418 \pm 13$ & $223 \pm 9$ & $2103 \pm 3$ \\
\hline $\mathrm{ENACW}_{T}$ & $15.30 \pm 0.4$ & $36.10 \pm 0.02$ & $2.24 \pm 1.7$ & $2.12 \pm 1.2$ & $0.15 \pm 0.05$ & $2363 \pm 10$ & $244 \pm 3$ & $2096 \pm 6$ \\
\hline$H$ & $12.20 \pm 0.4$ & $35.66 \pm 0.02$ & $3.98 \pm 1.8$ & $6.28 \pm 0.8$ & $0.39 \pm 0.01$ & $2338 \pm 15$ & $261 \pm 1$ & $2107 \pm 7$ \\
\hline $\mathrm{ENACW}_{P}$ & $8.30 \pm 0.3$ & $35.23 \pm 0.01$ & $10.33 \pm 0.6$ & $9.58 \pm 1.3$ & $0.73 \pm 0.08$ & $2320 \pm 7$ & $285 \pm 2$ & $2112 \pm 12$ \\
\hline $\mathrm{AA}$ & $7.50 \pm 0.1$ & $35.00 \pm 0.02$ & $24.90 \pm 0.8$ & $12.40 \pm 3.3$ & $0.96 \pm 0.3$ & $2320 \pm 1$ & $290 \pm 2$ & $2092 \pm 4$ \\
\hline MW & $11.74 \pm 0.1$ & $36.50 \pm 0.01$ & $8.62 \pm 0.8$ & $5.16 \pm 0.8$ & $0.31 \pm 0.1$ & $2411 \pm 1$ & $262 \pm 5$ & $2151 \pm 4$ \\
\hline LSW & $3.40 \pm 0.2$ & $34.89 \pm 0.12$ & $9.85 \pm 2.5$ & $12.03 \pm 0.7$ & $0.91 \pm 0.02$ & $2301 \pm 7$ & $320 \pm 2$ & $2118 \pm 19$ \\
\hline NEADW $u$ & $2.40 \pm 0.003$ & $34.93 \pm 0.003$ & $35.00 \pm 6$ & $11.95 \pm 0.2$ & $0.90 \pm 0.07$ & $2359 \pm 2$ & $328 \pm 2$ & $2139 \pm 22$ \\
\hline NEADW $l$ & $1.92 \pm 0.003$ & $34.88 \pm 0.002$ & $49.85 \pm 5$ & $12.94 \pm 0.4$ & $1.02 \pm 0.03$ & $2360 \pm 2$ & $332 \pm 3$ & $2147 \pm 10$ \\
\hline ISOW & $1.93 \pm 0.08$ & $34.96 \pm 0.02$ & $11.12 \pm 5$ & $9.26 \pm 2.7$ & $0.85 \pm 0.13$ & $2290 \pm 3$ & $331 \pm 3$ & $2099 \pm 4$ \\
\hline$W$ & 15 & 10 & 2 & 2 & 0.8 & 0.5 & 3.2 & 0.5 \\
\hline$r^{2}$ & 0.9998 & 0.9993 & 0.998 & 0.996 & 0.991 & 0.98 & 0.998 & 0.98 \\
\hline Std. Err. & 0.06 & 0.01 & 0.67 & 0.4 & 0.05 & 3.0 & 1.6 & 4.2 \\
\hline Rel. Err. & 1.9 & 0.8 & 1.7 & 1.2 & 0.9 & 1.5 & 1.3 & 1.3 \\
\hline
\end{tabular}

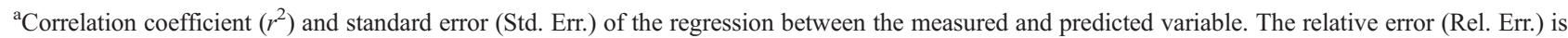
the standard error of the model residuals below 400 dbar divided by the analytical error. Number of data $=1743$. Abbreviations are as follows: MMW, Madeira Mode Water; ENACW ${ }_{T}$, Eastern North Atlantic Central Water Subtropical; ENACW ${ }_{p}$, Eastern North Atlantic Central Water Subpolar; $H$, lower limit of subtropical ENACW, upper limit of subpolar ENACW; AA, diluted Antarctic Intermediate Water; MW, Mediterranean Water; LSW, Labrador Sea Water; NEADW $u$ for Northeastern Atlantic Deep Water upper; NEADWl Northeastern Atlantic Deep Water lower; and ISOW, Iceland-Scotland Overflow Water.

tudes south of $33^{\circ} \mathrm{N}$ in agreement with several studies within the region [Tsuchiya et al., 1992; Pérez et al., 1998]. The figures comprising the type NEADW $u$ are just used along the Western wall, the model better resolves the mixing with this SWT instead of using LDW. A $\theta-S$ diagram for the entire data set, showing the SWT characteristics and mixing spaces is given in Figure 2.

[20] The NNLS method returns the squared largest singular value for the set of residuals resulting from the whole set of linear equations. This value is dimensionless and its magnitude has no meaning as it depends on the weights introduced, although its distribution and magnitude gives an idea of the model fit to the data. The total residual presents a mean \pm standard deviation of $0.14 \pm 0.23$, samples with a poorer fit are concentrated in the upper 400 dbar due to their higher thermohaline and chemical variability $(0.33 \pm 0.35)$, deeper samples are better resolved $(0.06 \pm 0.06)$.

[21] The correlation coefficient $\left(r^{2}\right)$ between the measured and expected values for the introduced tracers and the standard error (Std.Err.) of the corresponding residuals provide an estimation of the reliability of our mixing model. In the case of the tracers introduced in the model the $r^{2}$ values are higher than 0.97 and the corresponding Std.Err. of the residuals are low, $0.06^{\circ} \mathrm{C}, 0.01 \mathrm{psu}, 0.5,0.4,0.05$ and $1 \mu \mathrm{mol} \mathrm{kg}{ }^{-1}$, for $\theta, S, \mathrm{SiO}_{4}, \mathrm{NO}_{3}, \mathrm{PO}_{4}$ and $\mathrm{O}_{2}$, respectively, slightly higher than the corresponding measurement error $\left(0.01^{\circ} \mathrm{C}, 0.005 \mathrm{psu}, 0.3,0.2,0.04\right.$ and $0.6 \mu \mathrm{mol} \mathrm{kg}{ }^{-1}$,

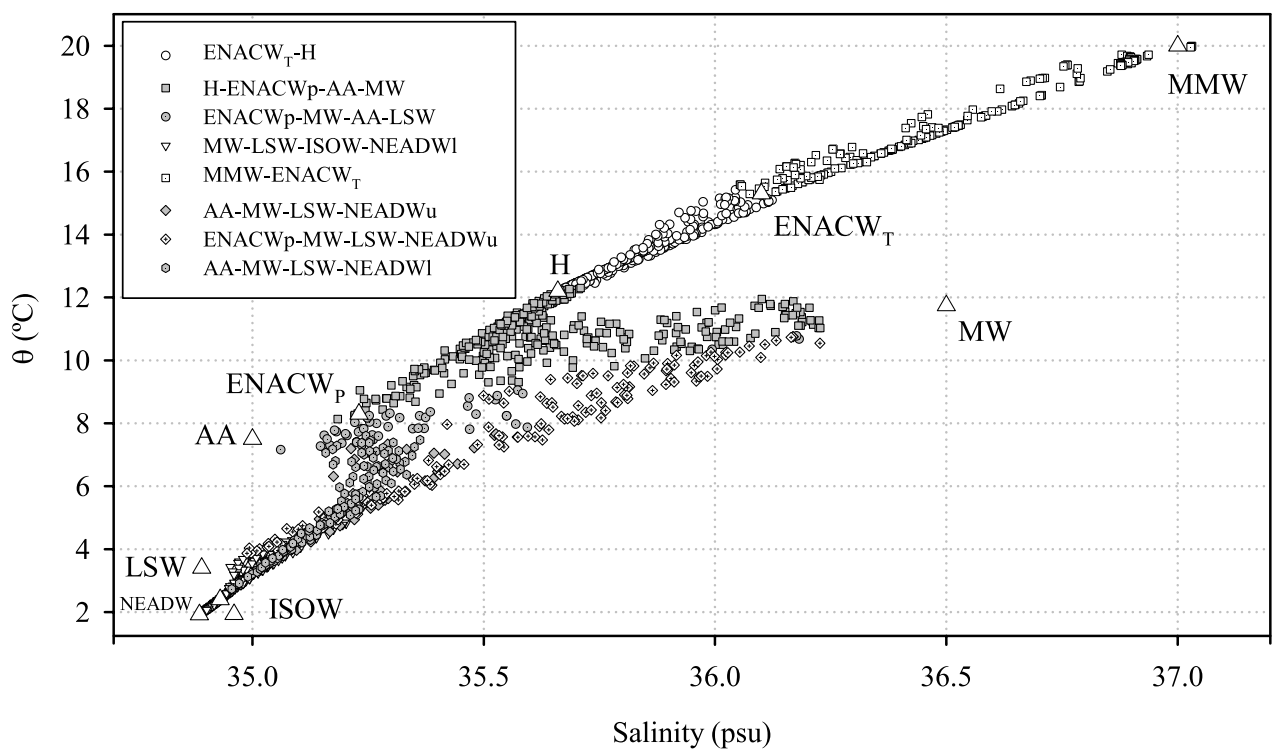

Figure 2. Potential temperature $(\theta)$-salinity $(S)$ diagram for bottle samples collected during the different cruises. Characteristics of the source water types are also represented. Samples belonging to surface waters are not included. 

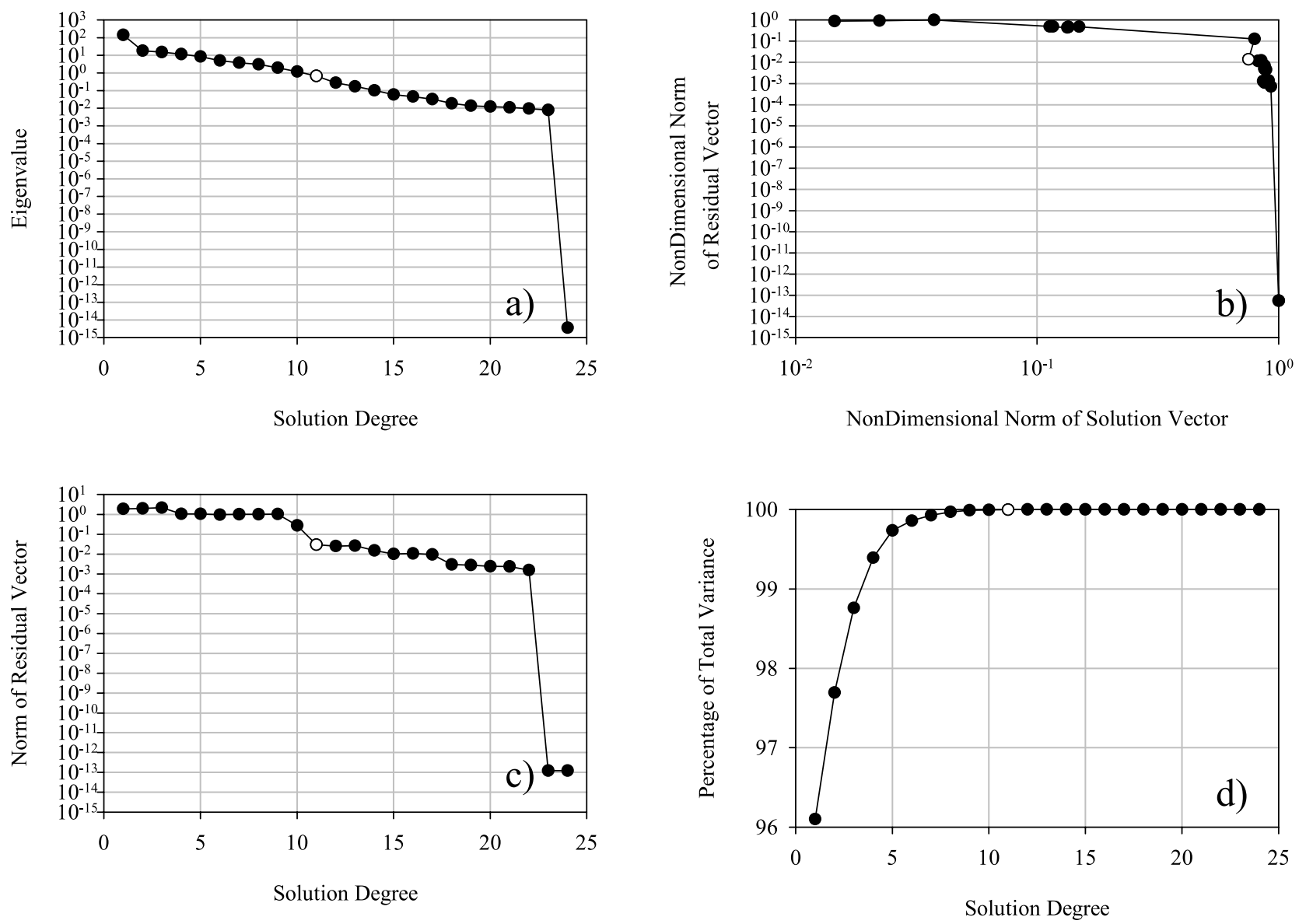

Figure 3. Four criteria used to estimate the preferred solution from the inverse model for the MedBox: (a) size of eigenvalue versus solution degree, (b) nondimensional norm of solution vector versus nondimensional norm of residual vector, (c) norm of residual vector versus solution degree, and (d) percentage of total variance versus solution degree. The selected solution at degree 11 is shown as a white circle.

respectively) (Table 2). We defined the relative error (Rel.Err.) of each introduced OMP variable as the standard error of the model residuals below 400 dbar divided by the corresponding analytical error, the Rel.Err. values are similar for all the variables, indicating that they are properly weighted. These results point to the reliability of the mixing model, able to reproduce with a high degree of confidence the thermohaline and chemical variability along the MedBox.

\subsection{Velocity Field}

[22] A complete and detailed description of the procedure to determine the velocity field is given by S\&B or Slater [2003]. They describe the treatment of the hydrographic data, their quality control, how to join sections, the treatment of the bottom triangles, the Ekman transport values and finally the geostrophic calculations slightly modified by an inverse model. Briefly, as previously mentioned, temperature and salinity data from the three cruises were checked for systematic differences in the NEADW domain. Corner or crossover stations (Figure 1) were created from the closest real stations which are not influenced by eddies. Isobaric averaging using linear regression was employed to create the corner stations. This method smoothes the tran- sition between the data sets but does not significantly change the actual data. The area below the deepest common level between each pair of stations or bottom triangles are treated separately, the velocity is linearly extrapolated from the velocity at the top of the triangle to zero at the bottom. Bottom triangles properties (SWT as well) are estimated using a weighted average of the values below the deepest common level. Ekman transport is estimated using the wind stress from the SOC climatology. Property values for the Ekman layer were taken from $\approx 50 \mathrm{~m}$.

[23] The velocity field is first approximated with the thermal wind equations using a reference level of $\sigma_{3}=$ 41.49 , virtually equivalent to 3200 dbar. From this initial velocity field, an inverse model is run (S\&B). Inverse models, pioneered by Wunsch [1978], solve underdetermined systems, where the unknowns, corrections to the reference level velocities, have to satisfy a series of constraints placed. The system of linear equations is underdetermined; there are an infinite number of solutions, the chosen one departs minimally from the initial state. Here the inverse model is solved by means of a singular value decomposition (SVD) which provide a series of eigenvalues from which the solution, so the barotropic corrections to be summed to each pair of stations, can be calculated. The 


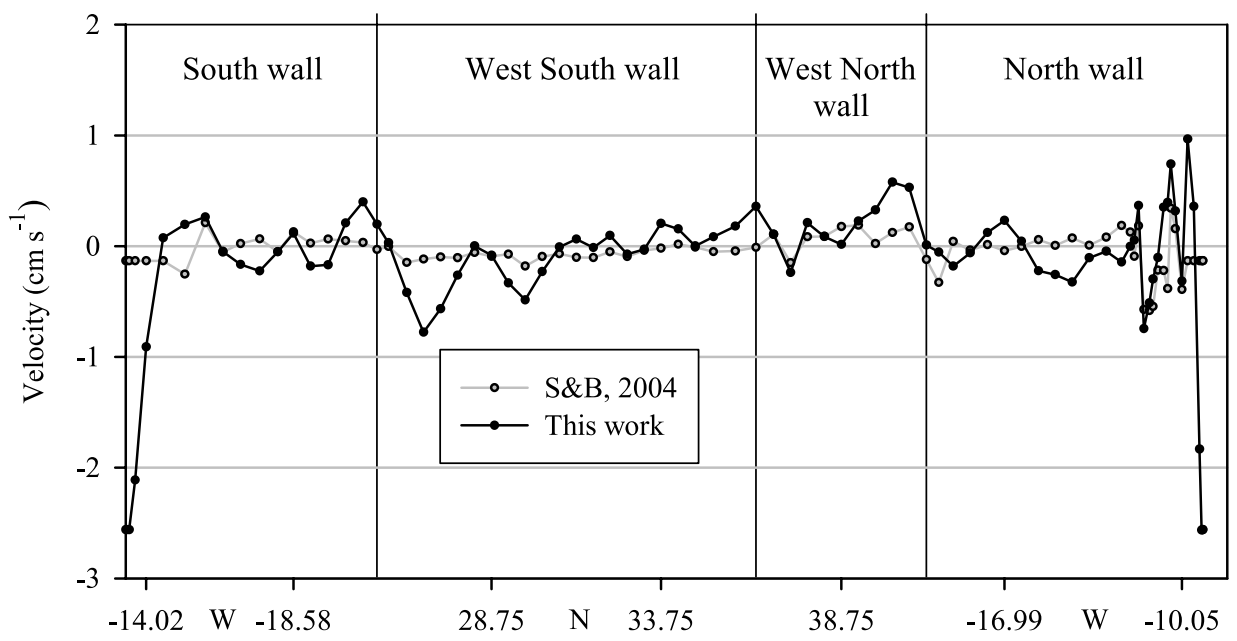

Figure 4. Selected barotropic corrections $\left(\mathrm{cm} \mathrm{s}^{-1}\right)$ obtained from the inverse model in this work and from $\mathrm{S} \& \mathrm{~B}$.

unknowns are scaled by the square root of the area between each station pair, which is equivalent to treating each station pair equally regardless of its area. The model conserves mass for the whole water column and mass, salt and heat fluxes for six deep layers below 2500 dbar (a total of 19 constraints (see S\&B for a full description)). Additional equations or constraints are added to this inverse model so that the net transport within the MedBox of deep waters (NEADW, LSW and ISOW) is zero, that is, there is no deep water formation within the MedBox as logically expected. Additionally, and in agreement with Alvarez et al. [2002] the transport of waters below 2000 dbar across the Northern wall is constrained to be $2 \mathrm{~Sv}$ northward, out of the box. Therefore five new constraints are added to the inverse model, giving a total of 24 . The equations are scaled by their norm, so all the constraints are equally important. The inverse model produces 24 eigenvalues, so 24 solutions, the higher the solution degree the closer the system is to the exact solution but the more noise is introduced into the system. In this sense the chosen solution should be a compromise between the magnitude of the residuals and the noise finally introduced.

[24] The same tests as in S\&B are used to select the solution degree. First, the relative magnitude of the eigenvalues, this method selects the eigenvalue just before a sharp decrease in their size. In this case, there is no clear sharp change (Figure 3a), although at solution 11 the eigenvalues' variation tendencies or slopes change to a lower value. The second test studies the magnitude of the solution and residual vectors, the solution vector increases as more information is added to the system, and correspondingly the residual vector decreases (Figure 3b). Solution degree 11 occurs after a sharp drop in the residual vector when the solution vector decreases. A sharp drop in the norm of the residual vector magnitude (Figure $3 \mathrm{c}$ ) points to solution degree 11 as the preferred one. Finally, Figure $3 \mathrm{~d}$ shows how much of the solution variance is explained by each eigenvalue, solutions higher than 9 explain almost $100 \%$ of the variance. These tests combined with a careful study of the constraints' residuals point to solution 11 as the preferred or optimal one.
[25] A short comparison and justification of our results compared to those of S\&B will be given. Figure 4 shows the solution or barotropic velocity corrections introduced by the inverse model of S\&B $\left(-0.054 \pm 0.17 \mathrm{~cm} \mathrm{~s}^{-1}\right)$ and this work $\left(-0.24 \pm 0.8 \mathrm{~cm} \mathrm{~s}^{-1}\right)$. Here we introduce more noise into the system, especially in the shallowest pairs of stations, as we require more constraints to be satisfied relatively stringently. The solution of $\mathrm{S} \& \mathrm{~B}$ drives a transport of salt out of the MedBox equal to $-2.241 \mathrm{~Sv}$ psu (remember that negative fluxes indicate a transport out of the box (see Table 3)), which translates into a freshwater transport into the box of $0.0636 \mathrm{~Sv}$ in perfect agreement with the estimation of evaporation within the MedBox and Mediterranean Sea given by the SOC climatology.

[26] The formation of MW within the MedBox drives an overturning circulation estimated as the magnitude of the upper inflow into the MedBox, according to $\mathrm{S} \& \mathrm{~B}, 3.58 \mathrm{~Sv}$ (Table 3). Combining the OMP analysis with their velocity field net transports for LSW, LDW and ISOW of -0.79 , 0.05 and $-0.05 \mathrm{~Sv}$, respectively were obtained (Table 3). The latter two water mass budgets can be considered acceptable, however the relatively high net transport of LSW out of the box implies that this water mass is formed within the region, which we know is not the case. The main factor leading to this net LSW transport is the velocity field and not the mixing analysis. A sensitivity test was performed varying the LSW type characteristics to $2.9^{\circ} \mathrm{C}$ and $34.84 \mathrm{psu}$ and a similar net transport was obtained, $-0.9 \pm 0.2 \mathrm{~Sv}$.

[27] Despite this, the results presented by S\&B or Slater [2003] are entirely reliable for the physical processes they want to study. However, as one of the aims of this work is to thoroughly describe the circulation of the different water masses and their relevance for the $C_{A N T}$ transport, we decided to introduce more constraints to the $\mathrm{S} \& \mathrm{~B}$ inverse model. As previously mentioned, no deep water formation is allowed and a northward transport of deep water in the Iberian Abyssal Plain is imposed. Table 3 also shows some of the new solution results, the salt outflow increases, as does the freshwater input into the MedBox; the overturning circulation is reduced but the MW transport remains the 
Table 3. Transports or Budgets Using the S\&B Velocity Field and That in This Study ${ }^{\mathrm{a}}$

\begin{tabular}{lcc}
\hline & S\&B & This Study \\
\hline Salt transport, Sv psu & -2.241 & $-2.981 \pm 0.3$ \\
Freshwater, Sv & 0.0636 & $0.0846 \pm 0.009$ \\
Overturning circulation, Sv & 3.58 & $2.87 \pm 0.07$ \\
C $_{\text {ANT transport, kmol s }}{ }^{-1}$ & 62 & $66 \pm 14$ \\
Central Waters transport, Sv & 2.65 & $2.5 \pm 0.2$ \\
AA transport, Sv & 0.85 & $0.2 \pm 0.2$ \\
MW transport, Sv & -2.71 & $-2.7 \pm 0.2$ \\
LSW transport, Sv & -0.79 & $-0.02 \pm 0.03$ \\
LDW transport, Sv & 0.05 & $-0.002 \pm 0.1$ \\
ISOW transport, Sv & -0.05 & $0.001 \pm 0.01$ \\
\hline
\end{tabular}

aplus-minus signs in the second column indicate error estimates (see section 3.3). See Table 2 for the water masses acronyms. The overturning circulation is defined as the net inflow of surface waters into the MedBox. positive values indicate a transport into the box. $1 \mathrm{~Sv}=10^{6} \mathrm{~m}^{3} \mathrm{~s}^{-1}$, and $1 \mathrm{kmol} \mathrm{s}^{-1}=1000 \mathrm{~mol} \mathrm{~s}^{-1}$.

same and finally, as constrained, the net transport of deep waters is negligible. Regarding the freshwater flux, it should be equivalent to the evaporation minus precipitation minus river runoff balance within the MedBox. The estimation given by $\mathrm{S} \& \mathrm{~B}$ is in agreement with the SOC global air-sea heat and momentum flux climatology [Josey et al., 1998], whereas our new slightly higher estimate is more in agreement with one based on the maps of evaporation minus precipitation for the North Atlantic by Schmitt et al. [1989], $0.086 \pm 0.009 \mathrm{~Sv}$.
[28] The main differences between both velocity fields are in the deep layer below about 2000 dbar. Figure 5 shows the profiles of total mass transport for the MedBox and the defined walls. The total transport profiles are very similar for both solutions, but the new one exaggerates the deep positive/into and negative/out of the box transports in the west north and northern walls, respectively. The west north and north walls present the highest LSW contributions (Figure 7c), and the inverse model is constrained to obtain an outflow in the north wall, so the only place to compensate the LSW imbalance is the west north wall. Here the velocities are increased toward higher positive values, whereas in the northern wall the transport is changed toward negative values to obtain a mass transport out of the box.

\subsection{Sensitivity Analysis}

[29] With the aim of assessing the impact of temporal changes on the end-members characteristics over their distributions and eventually in the transports' estimations, we have performed a sensitivity analysis.

[30] The SWT matrix on Table 2 was modified randomly: normally distributed random numbers were multiplied by the error assigned to each tracer and SWT (Table 2), these numbers were then added to the nominal characteristics, to finally resolve the OMP system. The errors assigned to each SWT for temperature and salinity were taken from field studies about temporal variability of water masses [Roemmich and Wunsch, 1984; Read and

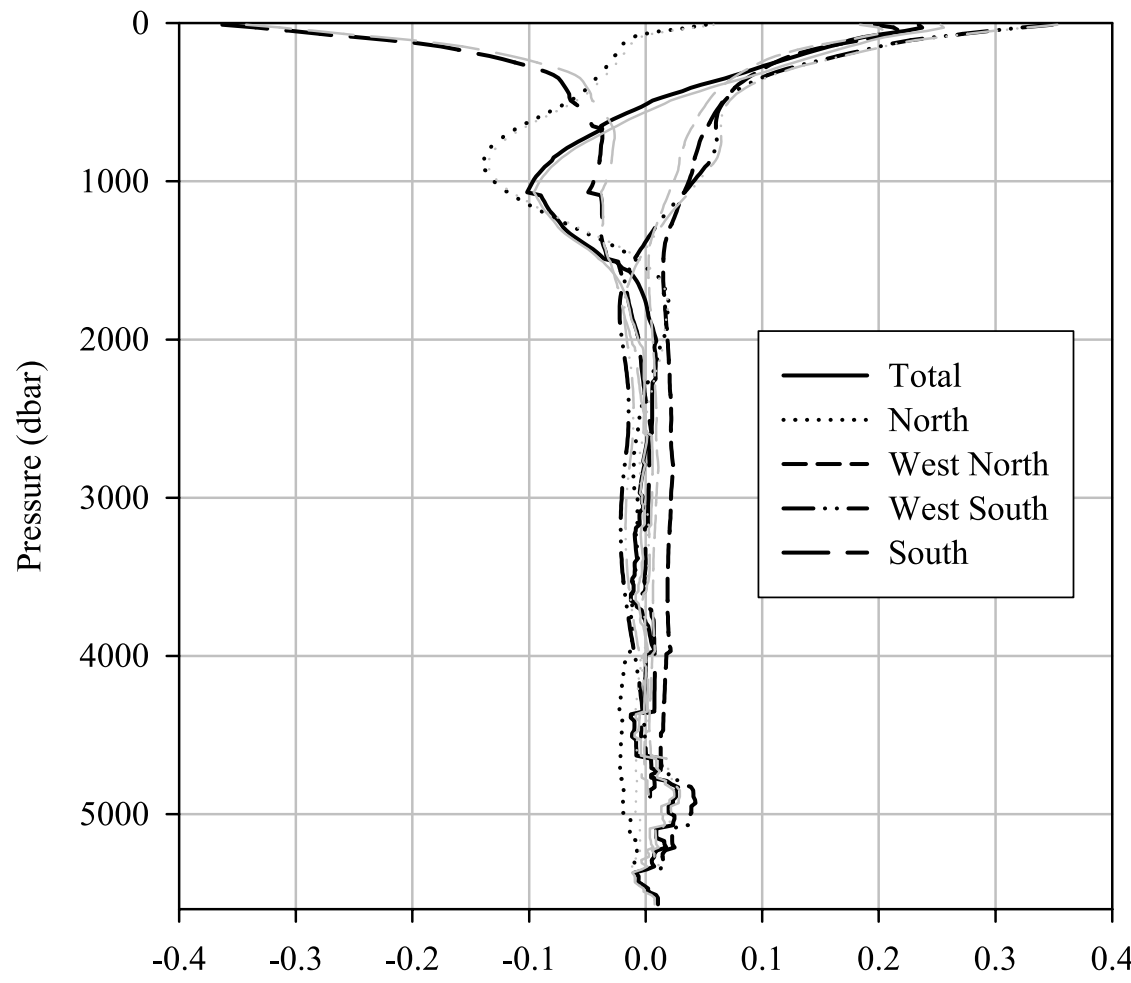

Sv per $20 \mathrm{~m}$

Figure 5. Profiles of mass transport for each wall defined in Figure 1 and the total MedBox as obtained in this work (black lines) and S\&B (shaded lines). Positive (negative) values indicate a transport into (out of) the MedBox. 
Table 4. Anthropogenic Carbon $\left(\mathrm{C}_{\mathrm{ANT}}\right)$ Transport Mechanisms in the MedBox ${ }^{\mathrm{a}}$

\begin{tabular}{lr}
\hline \multicolumn{1}{c}{ Transport } & $\mathrm{kmol} \mathrm{s}^{-1}$ \\
\hline Barotropic & $14 \pm 1$ \\
Overturning/baroclinic & $72 \pm 4$ \\
Horizontal & $-20 \pm 11$ \\
Total & $66 \pm 14$ \\
\hline${ }^{a}$ Plus-minus signs indicate error estimates (see section 3.3$)$. & Positive \\
values indicate a transport into the box. $1 \mathrm{kmol} \mathrm{s}^{-1}=1000 \mathrm{~mol} \mathrm{~s}^{-1}$.
\end{tabular}

Gould, 1992; Bryden et al., 1996; Sy et al., 1997; Curry et al., 1998; Dickson et al., 2002; Pickart and Torres, 2002; Potter and Lozier, 2004]. Errors in the biogeochemical properties were extrapolated from the real data $\theta / S$ property regressions. A total of 100 perturbations were computed to then calculate the mean and range of the solution matrix, so the SWT percentages. This range gives an estimation of the stability of the mixing model. The mean and standard deviation of each water mass range after the 100 perturbations are $7 \pm 7 \%, 2 \pm 4 \%$, $2 \pm 2 \%, 4 \pm 5 \%, 3 \pm 4 \%, 3 \pm 4 \%$ for central waters, AA, MW, LSW, LDW, and ISOW, respectively. The former low values indicate that the water mass distributions vary slightly when modifying their characteristics in the source regions.

[31] After each perturbation we obtained a distribution of deep waters, LSW, LDW and ISOW, so the inverse model equations changed, and correspondingly the final solution and the transports of mass and $\mathrm{C}_{\mathrm{ANT}}$ as well. The error for the results here presented was also calculated as the range of the series of mass and $\mathrm{C}_{\mathrm{ANT}}$ transports obtained after each perturbation. Please see Tables 3, 4, and 5 and their comments on the corresponding section below.

[32] The results presented in the following sections about the SWT distributions, mass and $\mathrm{C}_{\mathrm{ANT}}$ transports represent the mean after the 100 perturbations.

\subsection{Mechanisms of Mass and $C_{A N T}$ Transport}

[33] In order to understand the mechanisms leading to the mass and $\mathrm{C}_{\mathrm{ANT}}$ transport, we have separated the geostrophic fluxes into three components: a barotropic term due to the net transport across the box; a baroclinic term due to the horizontally averaged vertical structure; and finally, a horizontal term due to the residual flow after the barotropic and baroclinic components have been subtracted, which is associated with the horizontal variations about the baroclinic profile. The baroclinic and horizontal components have no net mass flow, and in this case the barotropic one as well. The barotropic transport includes the Ekman layer, the net barotropic water column transport in the box and the bottom triangles. The baroclinic and horizontal transports are respectively associated with the meridional overturning circulation and the large-scale gyre circulation including smaller-scale eddies. To quantify these components for the mass and $\mathrm{C}_{\mathrm{ANT}}$ transport, the orthogonal velocity $(v)$ and $\mathrm{C}_{\mathrm{ANT}}$, are separated into a section-averaged value $\left(\langle\bar{v}\rangle\right.$ and $\left\langle\overline{\mathrm{C}_{\mathrm{ANT}}}\right\rangle$, respectively), a baroclinic profile of zonally averaged values at each depth $\left(\langle v\rangle(z)\right.$ and $\left.\left\langle\mathrm{C}_{\mathrm{ANT}}\right\rangle(z)\right)$, and the deviations from zonal averages (anomalies) for each pair of stations and depth $\left(v^{\prime}(x, z)\right.$ and $\left.\mathrm{C}_{\mathrm{ANT}}^{\prime}(x, z)\right)$. Hence

$$
\begin{aligned}
v= & \langle\bar{v}\rangle+\langle v\rangle(z)+v^{\prime}(x, z) \\
& \mathrm{C}_{\mathrm{ANT}}=\left\langle\overline{\mathrm{C}_{\mathrm{ANT}}}\right\rangle+\left\langle\mathrm{C}_{\mathrm{ANT}}\right\rangle(z)+\mathrm{C}_{\mathrm{ANT}}^{\prime}(x, z) .
\end{aligned}
$$

The corresponding transports are calculated as Barotropic component

$$
\rho_{S, T, P} \cdot\langle\bar{v}\rangle \cdot\left\langle\overline{\mathrm{C}_{\mathrm{ANT}}}\right\rangle \cdot \int L(z) d z
$$

Baroclinic component

$$
\int \rho_{S, T, P} \cdot\langle v\rangle(z) \cdot\left\langle\mathrm{C}_{\mathrm{ANT}}\right\rangle(z) \cdot L(z) d z
$$

Horizontal component

$$
\int \rho_{S, T, P} \cdot v^{\prime}(x, z) \cdot \mathrm{C}_{\mathrm{ANT}}^{\prime}(x, z) \cdot d z \cdot d x
$$

where $L(z)$ is the width of the section at each depth and $\int L(z) d z$ is the area of the section. Mass transport is expressed in Sverdrups $\left(10^{6} \mathrm{~m}^{3} \mathrm{~s}^{-1}\right)$, so density is not introduced in its calculations. $\mathrm{C}_{\mathrm{ANT}}$ transport is given in $\mathrm{kmol} \mathrm{s}^{-1}\left(10^{3} \mathrm{~mol} \mathrm{~s}^{-1}\right)$.

\section{Distribution of Water Masses}

[34] Before dealing with the mass transport across the MedBox, paying particular attention to the circulation of the different water masses, it is worth describing their distribution around the MedBox. The main thermohaline structure found in the upper $500 \mathrm{dbar}$ is the front associated with the Azores Current (Figures $6 \mathrm{a}$ and $6 \mathrm{~b}$ ) at $\approx 32.5^{\circ} \mathrm{N}$ latitude and $-21.3^{\circ} \mathrm{W}$ longitude in agreement with the classical studies of Krauss and Meincke [1982] and Klein and Siedler [1989]. Warmer and more saline upper waters are found south of the front. Between 500 and 1500 dbar is the salinity maximum associated with MW on the northern wall and west north wall and the salinity minimum related to AA on the southern wall. Deep waters below 2000 dbar present the typical homogeneous temperature and salinity distribution.

[35] Upper $\mathrm{C}_{\mathrm{ANT}}$ (Figure 6c) estimations were disregarded where oxygen values are oversaturated, as they would lead to an overestimation of $\mathrm{C}_{\mathrm{ANT}}$, so the shallowest

Table 5. Anthropogenic Carbon $\left(\mathrm{C}_{\mathrm{ANT}}\right)$ Transport by Water Masses in the MedBox ${ }^{\mathrm{a}}$

\begin{tabular}{lr}
\hline Water Mass & $\mathrm{kmol} \mathrm{s}^{-1}$ \\
\hline Central Waters & $144 \pm 8$ \\
AA & $2 \pm 4$ \\
MW & $-88 \pm 8$ \\
LSW & $3 \pm 4$ \\
LDW & $4 \pm 2$ \\
ISOW & $1 \pm 1$ \\
\hline
\end{tabular}

${ }^{a}$ Plus-minus signs indicate error estimates (see section 3.3). See Table 2 for the water masses acronyms. Positive values indicate a transport into the box. $1 \mathrm{kmol} \mathrm{s}^{-1}=1000 \mathrm{~mol} \mathrm{~s}^{-1}$ 

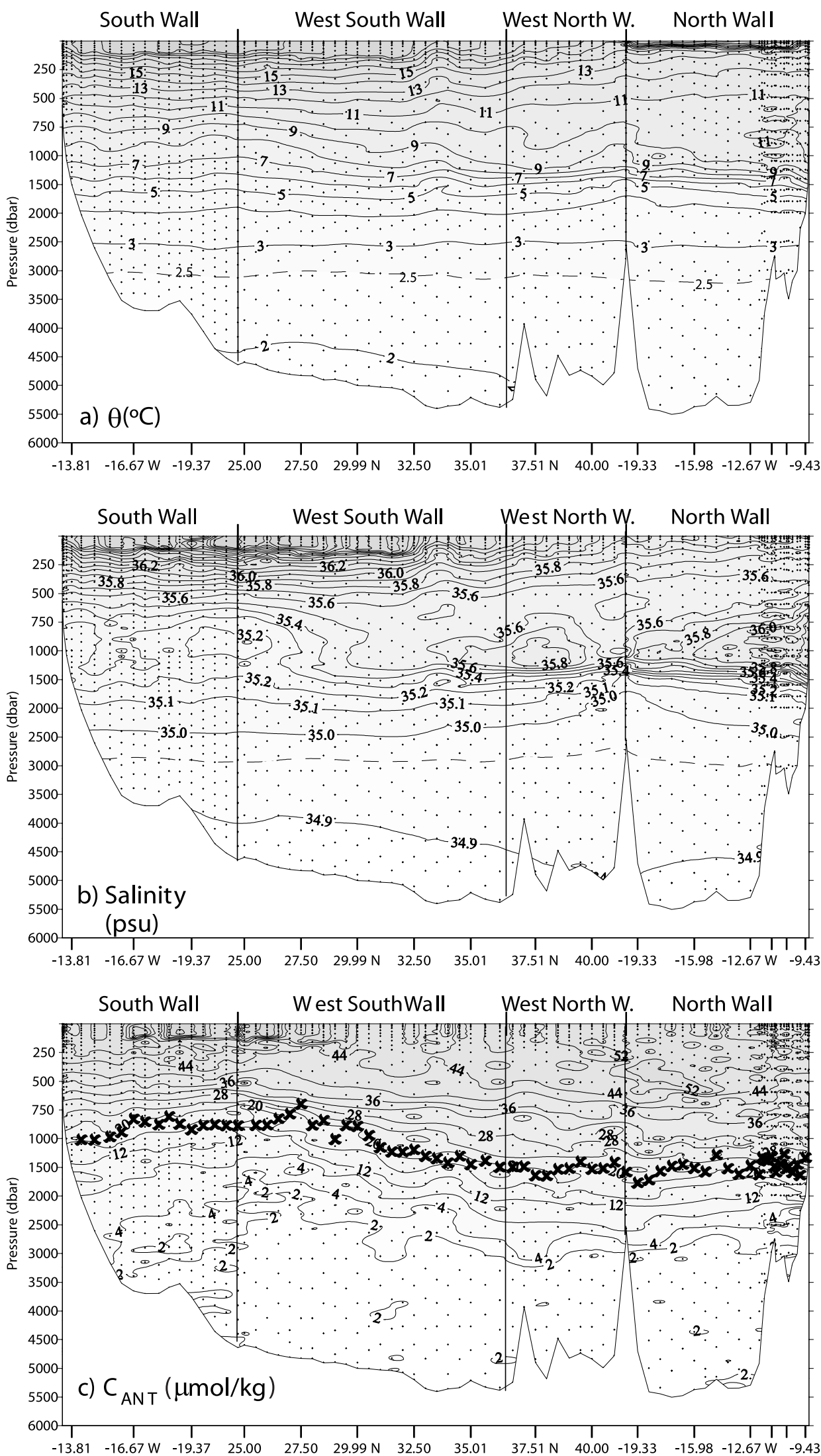

Figure 6. Vertical distribution of (a) potential temperature $\left(\theta\right.$ in $\left.{ }^{\circ} \mathrm{C}\right)$, (b) salinity (psu), and

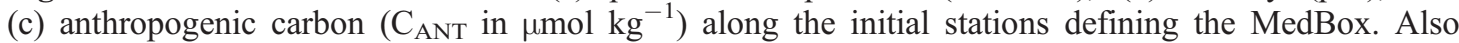
shown is the mean penetration depth of $\mathrm{C}_{\mathrm{ANT}}$ in the corresponding plot. Note the different scale for the upper $1000 \mathrm{dbar}$. 
proper $\mathrm{C}_{\mathrm{ANT}}$ values were extrapolated to the surface. Although not very clear in Figure 6c, the seasonal thermocline in the south has higher $\mathrm{C}_{\mathrm{ANT}}$ concentrations than northward. However, in the upper $500 \mathrm{dbar}$, the distance between $\mathrm{C}_{\mathrm{ANT}}$ isolines gets thicker northward, these waters accumulate more $\mathrm{C}_{\mathrm{ANT}}$ as they are colder. In the lower water column, $\mathrm{C}_{\mathrm{ANT}}$ isolines clearly get deeper northward as accordingly does the $\mathrm{C}_{\mathrm{ANT}}$ mean penetration depth (MPD), defined by Broecker et al. [1979] as

$$
\mathrm{MPD}=\frac{\int \mathrm{C}_{\mathrm{ANT} z} d z}{\mathrm{C}_{\mathrm{ANT} m l}},
$$

where $\mathrm{C}_{\mathrm{ANT} z}$ and $\mathrm{C}_{\mathrm{ANT} m l}$ are the $\mathrm{C}_{\mathrm{ANT}}$ concentrations at any depth $(z)$ and at the mixed layer $(m l)$, respectively. The qualitative reasons explaining this fact are the high proportion of relatively old $\mathrm{AA}$ with low $\mathrm{C}_{\mathrm{ANT}}$ to the south contrasting with the predominance of MW to the north, as MW, when formed in the Gulf of Cadiz, entrains $\mathrm{C}_{\mathrm{ANT}}$ laden central waters to depth. Also, there should be higher proportions of relatively recently formed LSW which has higher $\mathrm{C}_{\mathrm{ANT}}$ concentrations northward. Section 6 quantifies the relative contribution of each water mass to the $C_{A N T}$ distribution in the eastern North Atlantic Basin.

[36] Central mode waters occupy the upper 1000 dbar along the MedBox boundaries (Figure 7a), the different modes distribute according to the common circulation knowledge in the area [Pollard and Pu, 1985; Rios et al., 1992; Pollard et al., 1996]: Madeira Mode Water occupies the upper 250 dbar south of the Azores Current (at $32.5^{\circ} \mathrm{N}$ ) and it is also carried within the Azores Countercurrent between $35^{\circ}$ and $37.5^{\circ} \mathrm{N}$. Modes of Subtropical ENACW predominate between 250 and 500 dbar south of $40^{\circ} \mathrm{N}$. North of this latitude subtropical ENACW replaces Madeira Mode Water in the upper 250 dbar. Subpolar ENACW is found below the subtropical mode and gets as expected, shallower northward.

[37] MW (Figure 7b) is centered at about $1200 \mathrm{dbar}$ along the northern wall, where contributions of up to $60 \%$ are found close to the Iberian margin, east of $-13^{\circ} \mathrm{W}$. Another maximum of $50 \%$ is found in the west north wall. South of $28^{\circ} \mathrm{N}$, MW contributions are lower than $20 \%$. Situated at around the same depth, AA competes with MW (Figures $7 \mathrm{~b}$ and $7 \mathrm{~d}$ ). AA is mainly found south of $27.5^{\circ} \mathrm{N}$, with two maxima at $\approx 1000$ dbar near the African margin (southern wall). Northward it rapidly dilutes, practically disappearing at $32.5^{\circ} \mathrm{N}$, the position of the Azores Current. Several studies using thermohaline data report that AAIW is quickly diluted with subpolar ENACW north of $20^{\circ} \mathrm{N}$ [Käse et al., 1986; Willenbrink, 1982; Reid, 1994]. The northward spreading of AAIW within the eastern North Atlantic is a topic of much debate: mixing studies based on temperature and salinity data, but also supported by biogeochemical data, arrive at contrasting conclusions, van Aken [2002] proposed the poleward advection of AAIW up to $35^{\circ} \mathrm{N}$ due to the high nutrient and high apparent oxygen utilization signal at the salinity minimum, on the contrary, Pérez et al. [2001] ascribes this maximum of biogeochemical properties to the remineralization of organic matter in the African coast linked to the upwelling system, and mark the AAIW limit at $28.5^{\circ} \mathrm{N}$. Here, we have gone one step further. The extended OMP analysis takes into account both the physical and biogeochemical mixing processes and allows the mixing of AA and subpolar ENACW, with biological aging included in the mixing scheme. A careful study of the mixing residuals was done around $33^{\circ} \mathrm{N}$ to check the AA northward extent, including it north of $33^{\circ} \mathrm{N}$ yielded higher residuals at intermediate levels. Our results point to the position of the Azores Current as the northern limit of AAIW-influenced water in the eastern North Atlantic.

[38] The main core of LSW lies at $1700 \mathrm{dbar}$, as expected higher contributions are found near the Iberian margin (northern wall) (Figure 7c). South of $30^{\circ} \mathrm{N}$, LSW rapidly mixes with AA in its upper layer and NEADW in the lower layer. The main deep water in the eastern North Atlantic is NEADW. Here, we just show the distribution of its lower limit, LDW, which predominates below 2500 dbar (Figure 7a) all along the MedBox. LDW entering the Vema fracture zone on its way northward toward the eastern North Atlantic mixes with LSW and ISOW giving rise to a very homogeneous water mass, upper NEADW, which is not shown here for the sake of simplicity in showing the results. Only small contributions of ISOW, less than $10 \%$, are detected in the study region (Figure $7 d$ ).

\section{Mass Transports, Mechanisms, and Budgets: Contribution of Water Masses}

[39] The combination of a mixing analysis with mass and biogeochemical transports provides new insights into the importance of the circulation and transport of physical and biogeochemical properties such as heat, freshwater or $\mathrm{C}_{\mathrm{ANT}}$ for the global ocean dynamics [Álvarez et al., 2004]. One of the strengths of this work lies in the quantification of the relative contribution of eastern North Atlantic water masses to the overturning circulation in this important region for the global ocean circulation, information that would eventually help to predict temporal changes due to global climate change.

[40] S\&B describe the general circulation in the MedBox with special emphasis on the MW transport. Briefly, the excess of evaporation over precipitation in the region of the MedBox and the Mediterranean Sea must be compensated by a net freshwater transport into the box. The air-sea interaction leads to the general circulation in the region. It consists of a relatively fresh upper layer flowing into the MedBox and ultimately into the Mediterranean Sea and a

Figure 7. Water mass contributions around the MedBox, vertically ordered: (a) central waters (sum of Madeira Mode Water (MMW), subtropical and subpolar Eastern North Atlantic Central Water (ENACW)), and Lower Deep Water (LDW); the lower limit of MMW and subtropical ENACW are shown as solid and dashed lines, respectively. (b) Mediterranean Water (MW). (c) Labrador Sea Water (LSW). (d) Diluted Antarctic Intermediate Water (AA) and Iceland-Scotland Overflow Water (ISOW). Note the different scale for the upper $1000 \mathrm{dbar}$. 

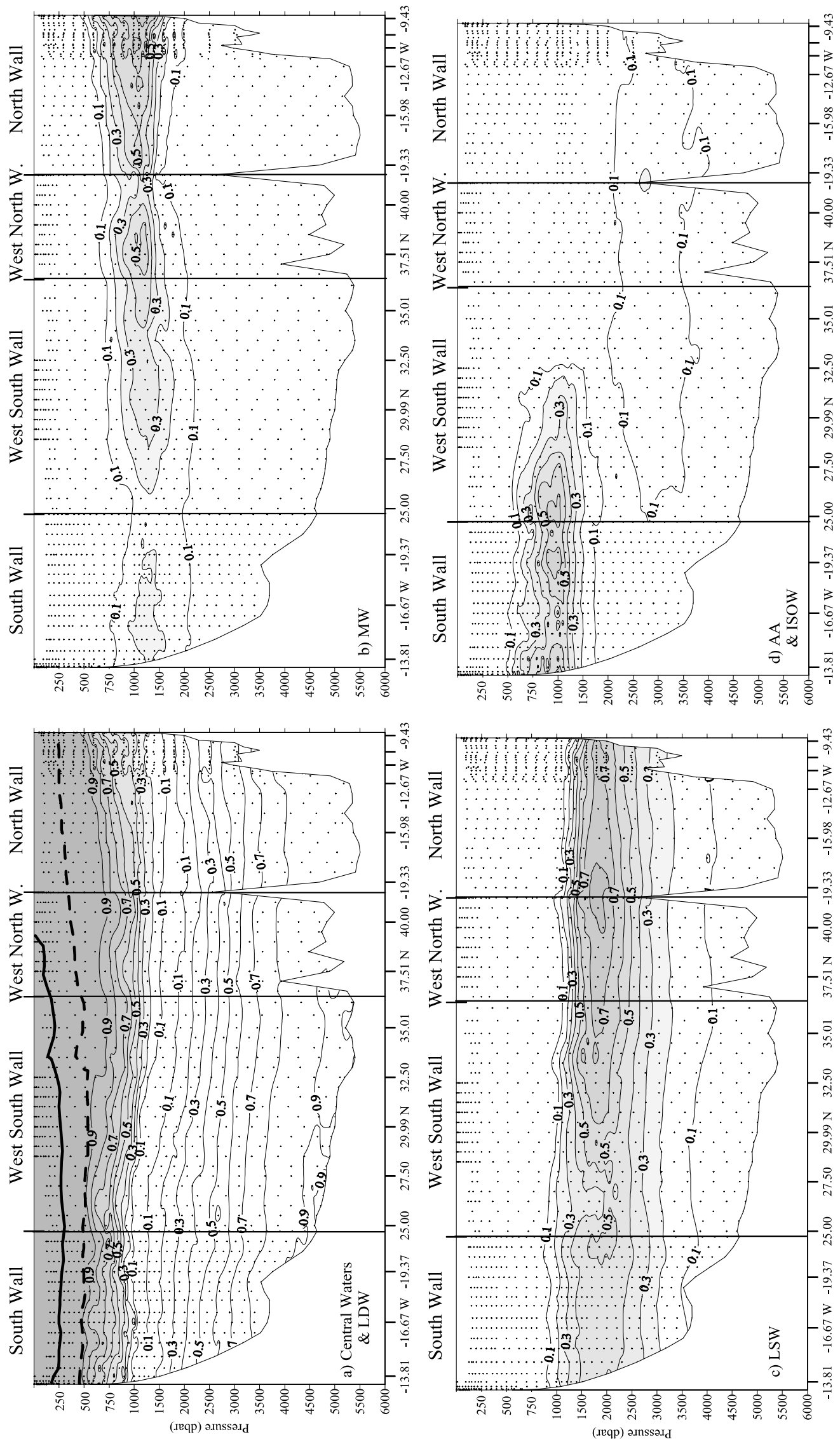

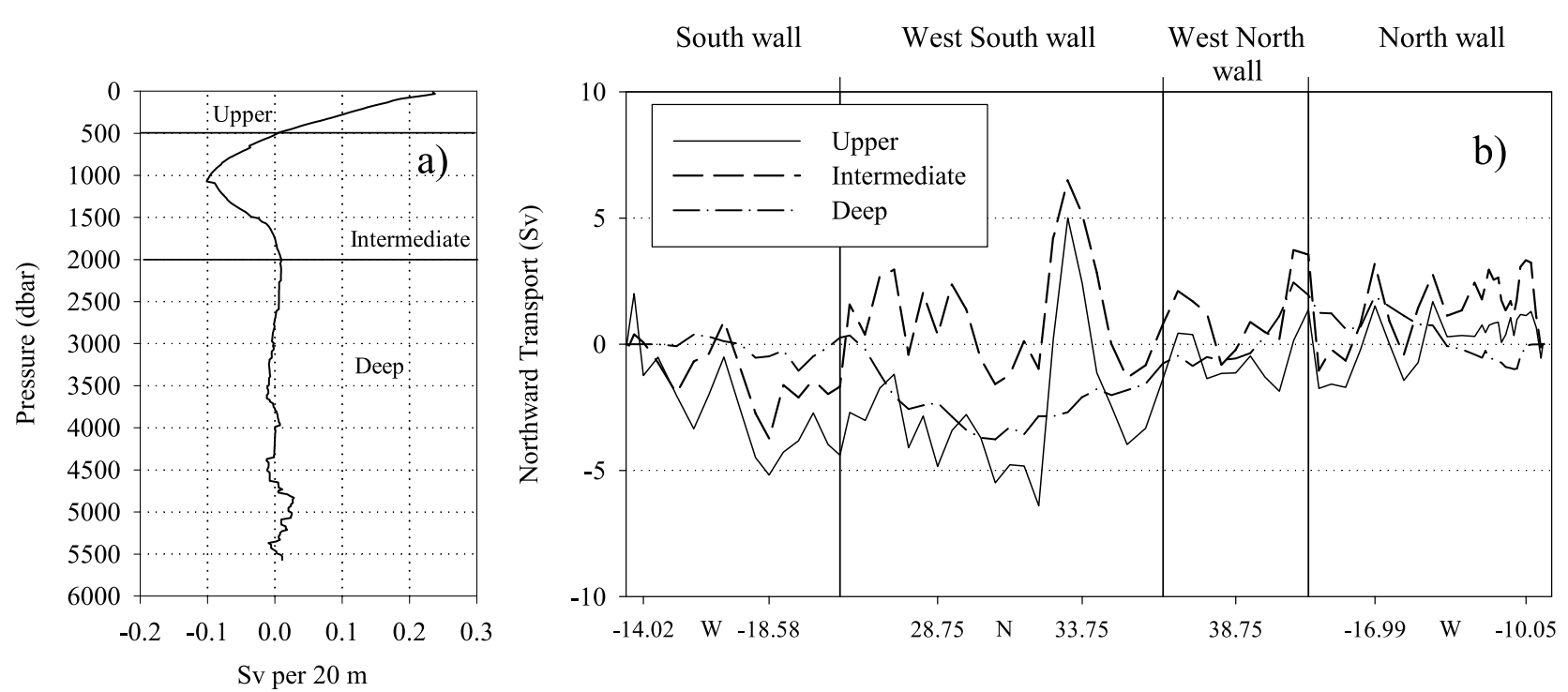

Figure 8. (a) Baroclinic and (b) horizontal mass transport for the MedBox. The horizontal transport is divided into three vertical layers shown in Figure $8 \mathrm{a}$ and accumulated from zero at the African margin $\left(1 \mathrm{~Sv}=10^{6} \mathrm{~m}^{3} \mathrm{~s}^{-1}\right)$. Positive (negative) values indicate a transport into (out of) the MedBox.

salty intermediate layer flowing out of the MedBox. This overturning circulation results from the entrainment of central waters into the high-salinity Mediterranean Outflow Water (MOW) coming out from the Strait of Gibraltar.

[41] The magnitude of the overturning circulation (inflow of upper waters) in MedBox 98 is estimated to be $\approx 3 \mathrm{~Sv}$ (Figure 8a, Table 3). From the OMP analysis, we know that only central waters are found above 500 dbar. Taking into account that the inflow to the Mediterranean Sea is about 0.7 Sv [Bryden et al., 1994] we can estimate that 2.3 Sv of central waters are dragged to depth when MW is formed. This is an estimation of the entrainment of central waters into the MOW. This figure agrees with the early work by Zenk [1975], 2-3 Sv; with that given by Rhein and Hinrichsen [1993], 2.6 Sv; by Baringer and Price [1997], 1.3 Sv, near Cape Saint Vincent; and finally the mean estimation given by $\mathrm{S} \& \mathrm{~B}, 1.6 \pm 0.6 \mathrm{~Sv}$.

[42] The outflow at the intermediate layer between 500 and 2000 dbar (Figure 8a) relates to MW flowing out of the MedBox into the North Atlantic. A total of $-3.5 \mathrm{~Sv}$ are transported out of the MedBox, being $-2.6 \mathrm{~Sv}$ of pure MW, $-0.7 \mathrm{~Sv}$ of central waters and $-0.3 \mathrm{~Sv}$ of LSW; within this layer there is an AA inflow of $0.2 \mathrm{~Sv}$ into the MedBox. Therefore when MOW entrains central waters to form MW and MW reaches its neutral density surface in the eastern North Atlantic, it flows at intermediate layers out of the region carrying with it small amounts of recirculating central waters and LSW, but AA is not incorporated into this outflowing core of salty water. The mass transport in the deep layer below 2000 dbar is small, only 0.4 Sv into the box, 65\% LSW and the rest LDW, which are mixed upward.

[43] The water mass budgets within the MedBox (Table 3) indicate that $\mathrm{MW}$ is produced at a rate of $2.7 \pm 0.2 \mathrm{~Sv}$, which come from the transformation of $2.5 \pm 0.2 \mathrm{~Sv}$ of Central Waters and $0.2 \pm 0.2 \mathrm{~Sv}$ of diluted Antarctic Intermediate Water. The $2.5 \mathrm{~Sv}$ of Central Waters include the $0.7 \mathrm{~Sv}$ transformed within the Mediterranean Sea into
MOW. In fact the budgets performed in this work comprise the MedBox and the Mediterranean Sea so the processes involved in the MW formation are the air-sea fluxes inducing deep convection in the Mediterranean Basin, and/or winter convection and other processes as entrainment in the MedBox.

[44] The horizontal circulation (Figure 8b) within the MedBox shows the known sluggish anticyclonic circulation within the region [Pollard and Pu, 1985; Ríos et al., 1992], with waters entering the box across the western walls and flowing out across northern and southern walls. Figure $8 \mathrm{~b}$ highlights the relatively high eddy activity along with the Azores Current crossing the west wall at about $31.7^{\circ}-$ $33.2^{\circ} \mathrm{N}$ and its countercurrent slightly to the north.

[45] The combination of the OMP with the transport field allowed us to discern the contribution of each water mass to the overturning circulation in the eastern North Atlantic, adding more details to the work done by S\&B, and exactly quantifying the transport accounted for by each water mass. Within the upper layer (500 dbar) only central waters are transported (Figure 9a) mainly entering the box across the western wall and going out southward, with only $-0.4 \mathrm{~Sv}$ flowing northward across the north wall. The upper layer circulation in the eastern North Atlantic between the North Atlantic Current (flowing northeastward) at about $46^{\circ} \mathrm{N}$ and the Azores Current (southwestward) at about $36^{\circ} \mathrm{N}$ is poorly defined, with subtropical ENACW moving northeastward and subpolar ENACW moving southward, creating a frontal area near the Finisterre Cape [Fraga et al., 1982; Ríos et al., 1992].

[46] The circulation at the intermediate level (Figure 9b) is more interesting: $85 \%$ of the MW formed within the box, i.e., $2.2 \mathrm{~Sv}$, flows northward near the Iberian margin, and equal amounts of MW $(-0.3 \mathrm{~Sv})$ are detected to flow out of the box across the west south and south walls. Curiously, across the west north wall there is a small $(0.3 \mathrm{~Sv})$ flow of MW into the box. S\&B ascribed the total salt flux in the intermediate layer between 500 and 1500 dbar to MW 

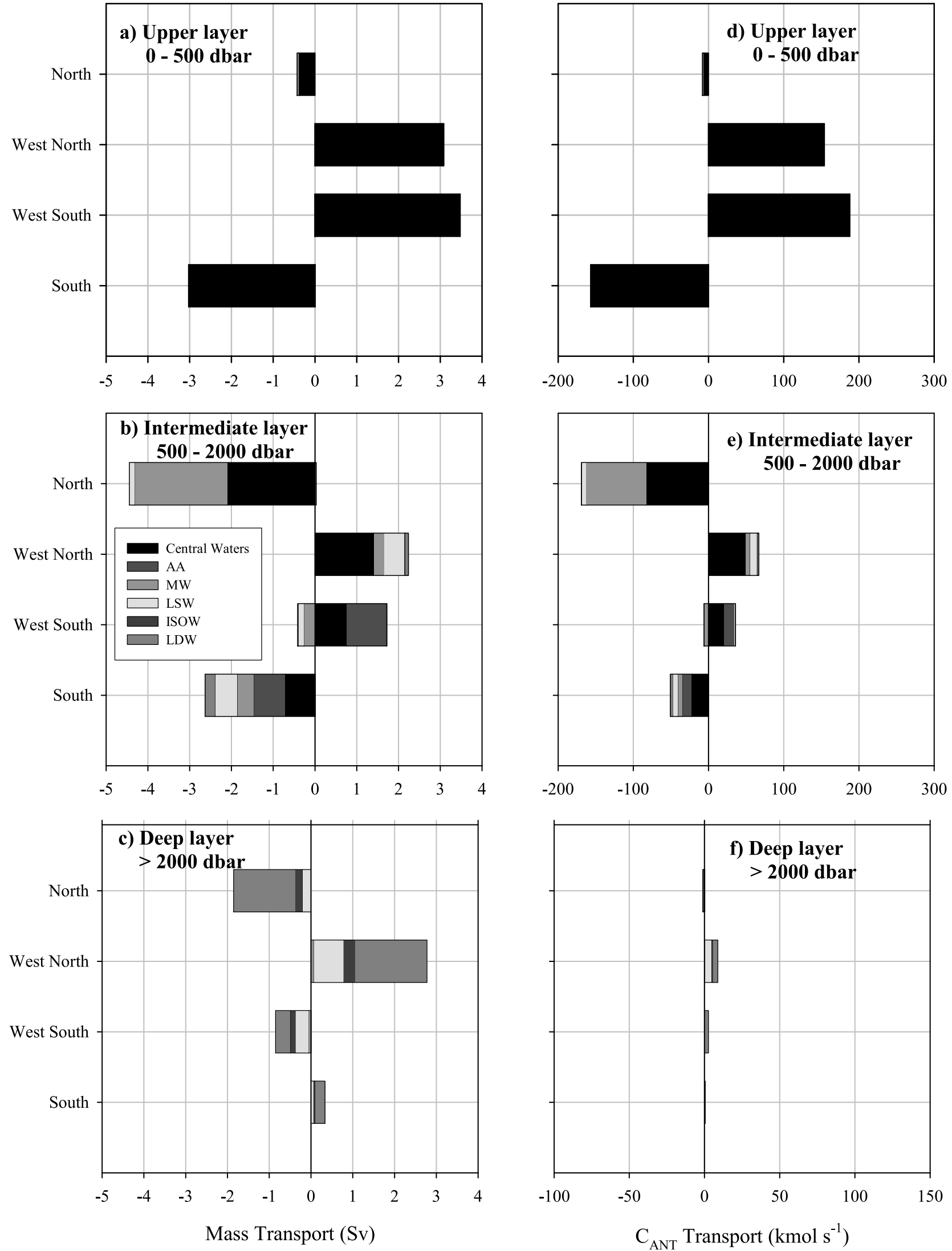

Figure 9 
transport, and calculated that $77 \%$ flows across the north wall and $23 \%$ across the west wall, with no flux across the south wall. The results here and of S\&B are both valid and complementary, however different as based on different methodologies. In this work we obtained the transport of pure MW, the water mass neutrally buoyant stabilized at about 1000 dbar in the Gulf of Cádiz. Therefore we are giving the total amount of MW exported from the MedBox and available to mix, no matter what mechanism, within the North Atlantic and to be incorporated into the global ocean circulation. So, $2.2 \mathrm{~Sv}$ flow into the northern North Atlantic, and $0.5 \mathrm{~Sv}$ must be incorporated into the subtropical eastern North Atlantic where likely mix with the Gulf Stream or North Atlantic Central Waters.

[47] If the MW mass transport is decomposed into components as described in section 3.4, we calculated that $63 \%$ of the total MW transport is due to the horizontal circulation in the intermediate layer. Therefore it is the large-scale gyre circulation and smaller-scale eddies/meddies (a meddy is a mesoscale vortex carrying MW for long periods of time and over thousands of kilometers [Armi et al., 1988; Käse et al., 1989]) the main mechanism responsible for the MW transport into the North Atlantic. As pointed out previously the horizontal mass transport (Figure $8 b$ ) shows a quite high eddy activity, indicating their relevance with respect to the small gyre circulation.

[48] Our scheme of MW circulation agrees with the qualitative study by Iorga and Lozier [1999a] showing the main spreading pathways of MW from a climatological data set. However, the same authors in an associated study [Iorga and Lozier, 1999b] conclude that there is no westward advection of MW at about $35^{\circ} \mathrm{N}$ as stated by Reid [1994] from observations and supported by the model results of Hogg [1987] and Bogden et al. [1993]. Other studies, such as Daniault et al. [1994] and Mazé et al. [1997], or the model by Paillet and Mercier [1996] argued that there is no direct advection of MW but westward meddy propagation. Here we introduce a different methodology to study the MW transport into the North Atlantic, we do not use salinity anomalies or study a given density interval, we asses the contribution of the pure MW end-member to the mass transport and the mechanisms implied. The results point to the Iberian margin as the main advection route of MW out of the MedBox, albeit there is a westward transport driven by eddies and the sluggish gyre circulation within the region. As concluded by Candela [2001] further research is required about the MW spreading in the North Atlantic.

[49] The AA circulation in the region is for the first time quantified: $1 \mathrm{~Sv}$ of this water mass enter the box at intermediate levels across the west south wall (Figure 9b), while $-0.7 \mathrm{~Sv}$ leaves the box southward. As previously said, about $0.2 \mathrm{~Sv}$ of AA (Table 3) is transformed into MW. These results are somehow surprising as AA is always thought to flow poleward in a slope current off Africa
[Reid, 1994; Tsuchiya, 1989] but, similar transports were also found by Lavin [1999] in the eastern Canary Basin portion of the $24.5^{\circ} \mathrm{N}$ WOCE section done in 1992 .

[50] The deep circulation (Figure 9c) shows some remarkable features: the deep cyclonic circulation in the Iberian Basin [Dickson et al., 1985], with deep waters entering the area from the southwest and flowing out northward. In this work we can discern and quantify the main pathways, a total of $0.3 \mathrm{~Sv}$ flow across the south wall into the box which continue northward incorporating $1.9 \mathrm{~Sv}$ crossing the west wall, finally $-1.9 \mathrm{~Sv}$ flow out of the box northward. We have quantified an upwelling of deep waters below 2000 dbar within the MedBox of $0.4 \mathrm{~Sv}$, in agreement with the theory by Stommel and Arons [1960] and the calculations by Arhan et al. [1994] along a quasi-meridional section in the eastern North Atlantic. This section lies inshore of the west wall but the deep circulation pattern, below $2000 \mathrm{dbar}$, inferred by the former authors agrees with our results along the west wall supporting them.

\section{C Ant Transports, Mechanisms, and Budgets: The Relevance of Mediterranean Water Formation}

[51] The $\mathrm{C}_{\mathrm{ANT}}$ budget within the region can be studied from different points of view. Here we attempt to produce a clear picture of the role of this region and particularly the formation of $\mathrm{MW}$ in the drawdown of $\mathrm{C}_{\mathrm{ANT}}$ within the framework of the current knowledge about the global ocean carbon cycle and a preliminary study within the region by Ríos et al. [2001].

[52] First, an overall look at this particular region of the eastern North Atlantic. The MedBox is only opened through the Strait of Gibraltar connecting it with the Mediterranean Sea (Figure 1). In order to study the $\mathrm{C}_{\mathrm{ANT}}$ budget within the region we need to know all the terms in the following equation:

$$
\text { Storage }=F_{\text {air-sea ANT }}+T_{\mathrm{W} \text { ANT }}+T_{\mathrm{E} \mathrm{ANT}},
$$

where the storage is positive and stands for the $\mathrm{CO}_{2}$ dissolved in the ocean as a result of the total or partial equilibration of surface ocean waters with the increasing atmospheric $\mathrm{CO}_{2}$ content; $F_{\text {air-sea }}$ is the air-sea $\mathrm{CO}_{2}$ flux in the region (positive into the region), $T_{\mathrm{W}}$ and $T_{\mathrm{E}}$ respectively refer to the net transport of carbon across the western (i.e., MedBox) and eastern (i.e., Strait of Gibraltar) boundaries of the area (positive into the region). The $\mathrm{C}_{\mathrm{ANT}}$ budget performed in this work is referred to 1998, when the cruises were done.

[53] The transport across the western boundary is directly estimated in this work, $66 \pm 14 \mathrm{kmol} \mathrm{s}^{-1}$ (Table 4). The $\mathrm{C}_{\mathrm{ANT}}$ transport across the Strait of Gibraltar can be indirectly and roughly estimated assuming that the $0.71 \mathrm{~Sv}$ inflow of central waters [Bryden et al., 1994; Tsimplis and

\footnotetext{
Figure 9. Water mass contribution to the $(a-c)$ mass and $(d-f) C_{A N T}$ transport across the north, west north, west south, and south walls of the MedBox (see Figure 1), divided into three vertical layers shown in Figure 8a: (a, d) upper layer, less than $500 \mathrm{dbar}$; (b, e) intermediate layer, between 500 and $2000 \mathrm{dbar}$; and (c, f) deep layer, below 2000 dbar $\left(1 \mathrm{~Sv}=10^{6} \mathrm{~m}^{3} \mathrm{~s}^{-1} ; \mathrm{kmol} \mathrm{s}^{-1}=1000 \mathrm{~mol} \mathrm{~s}^{-1}\right)$. Positive (negative) values indicate a transport into (out of) the MedBox. The water mass acronyms are those in Figure 7. Note the different scale in Figure 9f. See color version of this figure at back of this issue.
} 

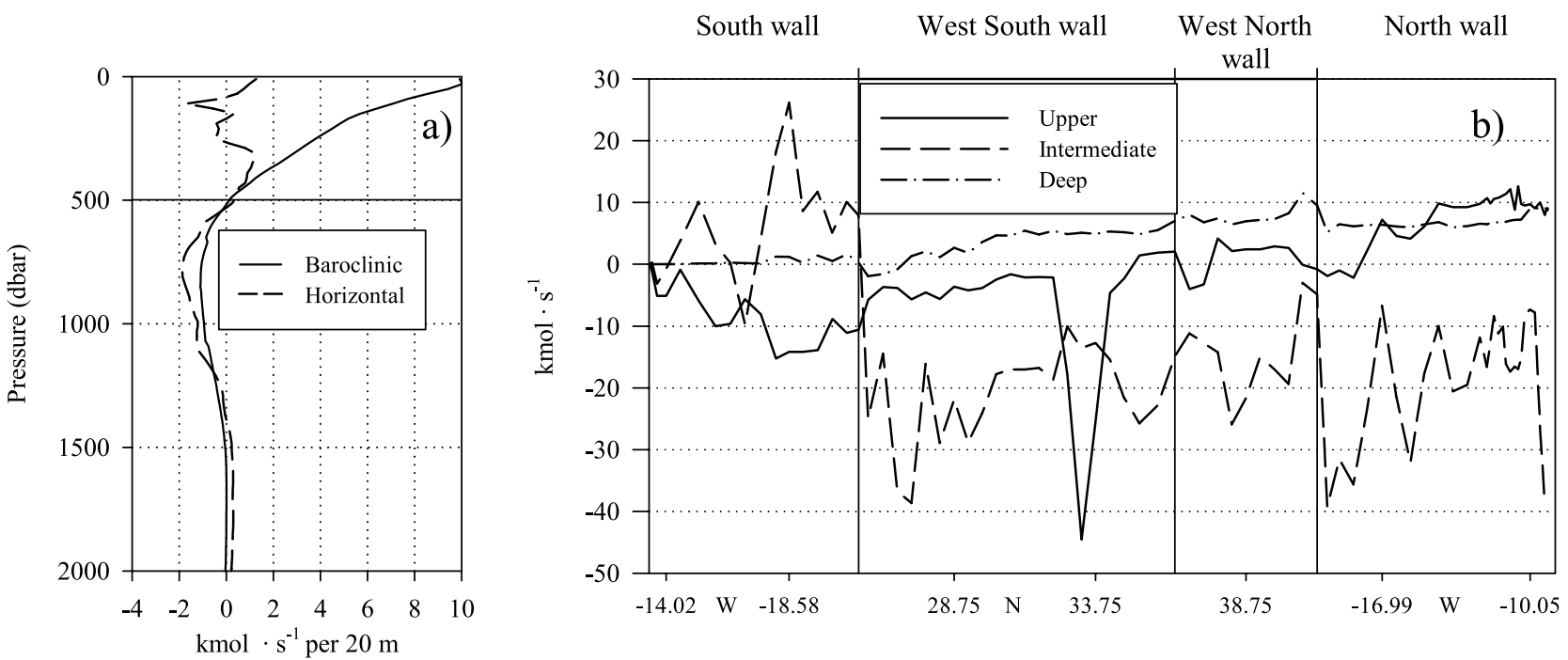

Figure 10. (a) Baroclinic and horizontal and (b) only horizontal anthropogenic carbon $\left(\mathrm{C}_{\mathrm{ANT}}\right)$ transport for the MedBox. The horizontal transport is divided into three vertical layers as in Figure $8 \mathrm{a}$ and accumulated from zero at the African margin $\left(\mathrm{kmol} \mathrm{s}^{-1}=1000 \mathrm{~mol} \mathrm{~s}^{-1}\right)$. Positive (negative) values indicate a transport into (out of) the MedBox.

Bryden, 1999] are saturated in $\mathrm{C}_{\mathrm{ANT}}$, about $50 \mu \mathrm{mol} \mathrm{kg}{ }^{-1}$; and that the $0.67 \mathrm{~Sv}$ of MOW flowing into the basin contain about $35 \mu \mathrm{mol} \mathrm{kg}{ }^{-1}$, calculated from CFC ages of about 15 years in the Alboran Sea [Rhein and Hinrichsen, 1993]. Therefore about $11 \mathrm{kmol} \mathrm{s}^{-1}$ of $\mathrm{C}_{\mathrm{ANT}}$ flow into the Mediterranean Sea, this quantity is subject to a high uncertainty, certainly direct estimates are needed.

[54] The storage can be estimated as by Álvarez et al. [2003]:

$$
\text { Storage }=\mathrm{MPD} \cdot \frac{d \mathrm{C}_{\mathrm{ANTml}}}{d t} .
$$

The mean $\mathrm{C}_{\mathrm{ANT}} \mathrm{MPD}$ in the region $(1182 \pm 382 \mathrm{~m}$, see Figure 6c) times the temporal increase of $\mathrm{C}_{\mathrm{ANT}}$ in the mixed layer, which is calculated assuming a fully $\mathrm{CO}_{2}$ equilibrated mixed layer keeping pace with the $\mathrm{CO}_{2}$ atmospheric increase $\left(0.92 \mu \mathrm{mol} \mathrm{kg} \mathrm{yr}^{-1}\right.$, as of Rios et al. [2001]). So about $66 \pm 21 \mathrm{kmol} \mathrm{s}^{-1}$ are accumulated within the water column of the MedBox.

[55] Consequently, to balance the $\mathrm{C}_{\mathrm{ANT}}$ budget within the MedBox $13 \mathrm{kmol} \mathrm{s}^{-1}$ of $\mathrm{C}_{\mathrm{ANT}}$ are absorbed from the atmosphere. From the point of view of the ocean, the water column is accumulating $\mathrm{C}_{\mathrm{ANT}}, 17 \%$ is absorbed from the atmosphere and $83 \%$ derives from the $\mathrm{C}_{\mathrm{ANT}}$ convergence driving by the circulation within the region. The previous work by Rios et al. [2001] based on a temporal series analysis and indirect mass transport estimates calculated that within the Iberian Basin the air-sea uptake was as important as advection for the $\mathrm{C}_{\mathrm{ANT}}$ storage.

[56] As the surface area of the MedBox is $1.710^{12} \mathrm{~m}^{2}$ the air-sea uptake can be translated into a mean air-sea flux of $0.7 \pm 0.7 \mathrm{mmol} \mathrm{C} \mathrm{m} \mathrm{m}^{-2} \mathrm{~d}^{-1}$. This is just the anthropogenic portion of the total air-sea $\mathrm{CO}_{2}$ flux, which is difficult to compare with as there are few regional estimates. However, this figure can be put into context, Álvarez et al. [2003] estimated in $0.9 \pm 0.8 \mathrm{mmol} \mathrm{C} \mathrm{m}^{-2} \mathrm{~d}^{-1}$ the
$\mathrm{C}_{\mathrm{ANT}}$ air-sea flux into the subpolar North Atlantic, $1.4 \pm$ $1.1 \mathrm{mmol} \mathrm{C} \mathrm{m} \mathrm{d}^{-1}$ in the temperate North Atlantic; between $24^{\circ} \mathrm{N}$ and $10^{\circ} \mathrm{S} 2.4 \mathrm{mmol} \mathrm{C} \mathrm{m} \mathrm{m}^{-2} \mathrm{~d}^{-1}$ were estimated by Rosón et al. [2003] and between $10^{\circ} \mathrm{S}$ and $30^{\circ} \mathrm{S}, 3.8 \mathrm{mmol} \mathrm{C} \mathrm{m} \mathrm{m}^{-2} \mathrm{~d}^{-1}$ by Holfort et al. [1998]. The MedBox seems to be a preferential area for the $C_{\text {ANT }}$ air-sea uptake given the small area it occupies relative to the other referred oceanic regions.

[57] What are the mechanisms driving the $\mathrm{C}_{\mathrm{ANT}}$ transport into the MedBox? The decomposition into components, calculated as explained in section 3.4, reveals that the overturning circulation is the main factor responsible for the $\mathrm{C}_{\mathrm{ANT}}$ input into the MedBox, while the horizontal circulation is exporting $\mathrm{C}_{\mathrm{ANT}}$ out of the box (Table 4, Figure 10). Figure 10b shows that the highest contribution to the horizontal transport comes from the intermediate layer. As the horizontal mass transport at this layer very much resembles that at the upper layer (Figure 8b) it is the contrasting $\mathrm{C}_{\mathrm{ANT}}$ content between the $\mathrm{C}_{\mathrm{ANT}}$ poor $\mathrm{AA}$ and the $\mathrm{C}_{\mathrm{ANT}}$ rich $\mathrm{MW}$ that results in the final $\mathrm{C}_{\mathrm{ANT}}$ horizontal transport.

[58] A summary of the $\mathrm{C}_{\mathrm{ANT}}$ mechanisms is given in Figure 10a: $C_{A N T}$ enters the MedBox in the upper layer mainly due to the overturning circulation within the region to finally form $\mathrm{MW}$. A portion of this $\mathrm{C}_{\mathrm{ANT}}$ is transported out of the box at intermediate layers with the MW core, but here the main mechanism exporting it out of the box is the horizontal circulation due to the contrasting $\mathrm{C}_{\mathrm{ANT}}$ content between AA (to the south of the MedBox (Figure 7d)) and MW (to the north (Figure 7b)). Quantitatively speaking, the horizontal component of the $\mathrm{C}_{\mathrm{ANT}}$ transport by $\mathrm{MW}$ is 2.8 times higher than the baroclinic one.

[59] The entrainment of central waters into MOW to finally form $\mathrm{MW}$ is a unique mechanism by which surface $\mathrm{C}_{\mathrm{ANT}}$ is injected to depth and then distributed at intermediate levels into the North Atlantic with the MW general circulation. Assuming an entrainment of 3-4 Sv (based on 
the works by Rhein and Hinrichsen [1993] and Mazé et al. [1997]) with a $C_{\mathrm{ANT}}$ concentration of $50 \mu \mathrm{mol} \mathrm{kg} \mathrm{kg}^{-1}$, Rios et al. [2001] calculated that $185 \mathrm{kmol} \mathrm{s}^{-1}$ are drawn down during the MW formation.

[60] In this work we can quantify two processes, the $\mathrm{C}_{\mathrm{ANT}}$ drawdown and that transported by MW into the North Atlantic. The $\mathrm{C}_{\mathrm{ANT}}$ drawn down to depth when $\mathrm{MW}$ is formed can be estimated performing a $\mathrm{C}_{\mathrm{ANT}}$ budget for the upper $500 \mathrm{dbar}$ in the MedBox. In this layer we calculated $177 \mathrm{kmol} \mathrm{s}^{-1}$ entering the MedBox minus the $\mathrm{C}_{\mathrm{ANT}}$ transport into the Mediterranean Sea, $11 \mathrm{kmol} \mathrm{s}^{-1}$, so about $166 \mathrm{kmol} \mathrm{s}^{-1}$, the air-sea flux introduces $13 \mathrm{kmol} \mathrm{s}^{-1}$ and about $28 \mathrm{kmol} \mathrm{s}^{-1}$ are accumulated, therefore $151 \pm$ $14 \mathrm{kmol} \mathrm{s}^{-1}$ should be entrained by MOW to form MW. Secondly, the amount of $\mathrm{C}_{\mathrm{ANT}}$ transported into the North Atlantic due to the spreading of MW out of the MedBox equals $-88 \pm 8 \mathrm{kmol} \mathrm{s}^{-1}$ (Table 5), mostly by the horizontal/eddy circulation $\left(-65 \mathrm{kmol} \mathrm{s}^{-1}\right)$.

[61] The relevance of $\mathrm{MW}$ in the global $\mathrm{CO}_{2}$ cycle can be put into context, $151 \pm 14 \mathrm{kmol} \mathrm{s}^{-1}\left(0.06 \pm 0.01 \mathrm{Gt} \mathrm{C} \mathrm{yr}^{-1}\right)$ are drawn down to depth when $\mathrm{MW}$ is formed and $88 \pm$

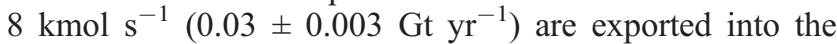
North Atlantic. For example, Tait et al. [2000] calculated $0.15-0.35 \mathrm{GtC} \mathrm{yr}^{-1}$ of $\mathrm{C}_{\mathrm{ANT}}$ flowing out of the Labrador Sea within the Western Boundary Undercurrent, assuming a volume flow of $18 \mathrm{~Sv}$ leaving the Labrador Sea. If lower Labrador Sea Water formation rates are used, between 4.4 and 5.6 Sv [Rhein et al., 2002], the amount of $\mathrm{C}_{\mathrm{ANT}}$ exported ranges between 0.06 and $0.08 \mathrm{GtC} \mathrm{yr}^{-1}$. Another example, the formation and export of SubAntarctic Mode Water north of the SubAntarctic Zone drives a $\mathrm{C}_{\mathrm{ANT}}$ uptake of 0.07-0.08 $\mathrm{GtC} \mathrm{yr}^{-1}$ [McNeil et al., 2001]. A recent review about the ocean as a $\mathrm{C}_{\mathrm{ANT}}$ sink estimates the role of intermediate waters formed in the Red Sea and Persian Gulf in the drawdown of $\mathrm{C}_{\mathrm{ANT}}$ into the Indian Ocean [Sabine et al., 2004]. These waters and MOW have a similar formation mechanism, an excess of evaporation increases the water salinity and density, which sink and carry $\mathrm{C}_{\mathrm{ANT}}$ to depth. The former authors estimate in $3 \mathrm{Pg} \mathrm{C}$ the $\mathrm{C}_{\mathrm{ANT}}$ inventory due to the Red Sea and Persian Gulf intermediate waters, so about $2.5 \%$ of the total $118 \mathrm{Pg} \mathrm{C}$ in the ocean. Given that the $\mathrm{C}_{\mathrm{ANT}}$ increase rate in the ocean is about $1.85 \mathrm{Gt} \mathrm{C} \mathrm{yr}^{-1}$,

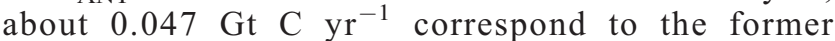
intermediate waters, value with the same order of magnitude as the $\mathrm{C}_{\mathrm{ANT}}$ drawn down to depth when $\mathrm{MW}$ is formed (0.06 Gt $\left.\mathrm{C} \mathrm{yr}^{-1}\right)$, pointing again to the relevant role of intermediate waters in carrying $\mathrm{C}_{\mathrm{ANT}}$ to depth.

[62] The spatial distribution of the $\mathrm{C}_{\mathrm{ANT}}$ transport within the MedBox accounted for by each water mass is shown in Figures $9 d-9 f$. The final contribution of each water mass to the $\mathrm{C}_{\mathrm{ANT}}$ transport is given in Table 5, central waters and MW are the main contributors, as they present the highest $\mathrm{C}_{\mathrm{ANT}}$ values (Figures $4 \mathrm{c}$ and 5 ) and the highest mass imbalances (Table 3), AA has a very low $\mathrm{C}_{\mathrm{ANT}}$ content (Figures 4c and 5d); and the deep ones, LSW, LDW and ISOW, very low $\mathrm{C}_{\mathrm{ANT}}$ content and a negligible mass imbalance (Table 3). The $\mathrm{C}_{\text {ANT }}$ transports in the deep layer (Figure 9f) can be considered as an indicative of the error of our methodology, about $10 \mathrm{kmol} \mathrm{s}^{-1}$, the same order as the total $C_{A N T}$ flux error, $14 \mathrm{kmol} \mathrm{s}^{-1}$. The $\mathrm{C}_{\mathrm{ANT}}$ input into the MedBox occurs in the upper layer carried by central waters entering the box through the west wall, whereas the main flow out of $\mathrm{C}_{\mathrm{ANT}}$ occurs at the intermediate layer across the north wall due to the outflow of central waters and MW.

\section{Summary}

[63] Combining portions of three WOCE sections sampled in 1997-1998 we defined a three-sided box in the eastern North Atlantic, the MedBox, encompassing the Strait of Gibraltar, so the formation region of Mediterranean Water (MW), known to have an important but still not well determined role in the global ocean thermohaline circulation.

[64] A careful study of the internal consistency was undertaken for the hydrographic (S\&B) and chemical (in this work) data to ensure uniformity across the data sets. The aim of this work was to study the magnitude, mechanisms and pathways of the mass and $\mathrm{C}_{\mathrm{ANT}}$ transport by water masses in the region with special emphasis on MW and its role in the global $\mathrm{CO}_{2}$ cycle. In order to accomplish these objectives an estimation of the mass and $\mathrm{C}_{\mathrm{ANT}}$ transport in the region obtained by an inverse model was coupled with a mixing analysis, an extended optimum multiparameter (OMP), that provides the contribution of the water masses. The inverse method was set following the work of S\&B, after having chosen the initial level of reference at $\sigma_{3}=41.49 \mathrm{~kg} \mathrm{~m}^{-3}$ close to $3200 \mathrm{dbar}$, the mass, salinity anomaly and heat flux within defined layers was constrained, deep water formation was not allowed and the deep layer transport across the northern boundary in the Iberian Abyssal Plain was constrained northward.

[65] The OMP resolved the mixing of 10 source water types (SWT) defining the water masses in the region and the biological activity defined as oxygen consumption by solving mixing equations for conservative variables (temperature, salinity and silicate) and nonconservative variables (nitrate, phosphate and oxygen). Mass was always conserved and SWT proportions always positive. Equations were properly weighted according to their variability and analytical uncertainty. The excess of unknowns relative to equations was overcome using vertically ordered mixing spaces and some SWT restrictions in agreement with the water mass dynamics in the region. The mixing analysis was proved to be reliable, able to reproduce the thermohaline and chemical variability along the MedBox. The most remarkable result from the OMP is that the Azores Current position seems to be the northern limit of influenced AAIW, at about $32^{\circ}-33^{\circ} \mathrm{N}$.

[66] The combination of the OMP analysis with the mass transport allowed us to estimate that $2.7 \pm 0.2 \mathrm{~Sv}$ of MW are produced within the MedBox, which come from the transformation of $2.5 \pm 0.2 \mathrm{~Sv}$ of central waters and $0.2 \pm 0.2 \mathrm{~Sv}$ of diluted AAIW. MW is mainly exported northward near the Iberian margin, 2.2 Sv, whereas about $0.5 \mathrm{~Sv}$ of MW flows into the subtropical eastern North Atlantic. The main mechanism exporting MW at intermediate levels is the horizontal circulation within the area, which also comprises the eddy activity.

[67] Regarding $\mathrm{C}_{\mathrm{ANT}}$, the MedBox is accumulating $\mathrm{C}_{\mathrm{ANT}}$ within the water column at a rate of $66 \pm 21 \mathrm{kmol} \mathrm{s}^{-1}, 17 \%$ of this $\mathrm{C}_{\mathrm{ANT}}$ is taken up through the air-sea interface, the rest is introduced by advection. The region is revealed as an 
important $\mathrm{C}_{\mathrm{ANT}}$ sink relative to the surface area, with a mean $\mathrm{C}_{\mathrm{ANT}}$ air-sea flux of $0.7 \pm 0.7 \mathrm{mmol} \mathrm{C} \mathrm{m}^{-2} \mathrm{~d}^{-1}$.

[68] The overturning circulation, responsible for the MW formation is introducing $\mathrm{C}_{\mathrm{ANT}}$ at a rate of $72 \pm 4 \mathrm{kmol} \mathrm{s}^{-1}$, whereas the horizontal circulation, mainly responsible for the MW export, is exporting $\mathrm{C}_{\mathrm{ANT}}$ out of the region at a rate of $20 \pm 11 \mathrm{kmol} \mathrm{s}^{-1}$. From the point of view of MW, the amount of $\mathrm{C}_{\mathrm{ANT}}$ drawn down to depth when formed is about

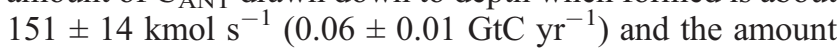
of $\mathrm{C}_{\mathrm{ANT}}$ exported with MW into the North Atlantic is $88 \pm$

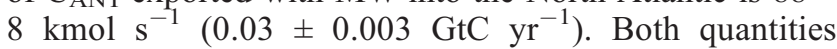
highlight the relevance of $\mathrm{MW}$ in the transport of $\mathrm{C}_{\mathrm{ANT}}$ to intermediate levels of the North Atlantic. The role of MW in the $\mathrm{C}_{\mathrm{ANT}}$ oceanic budget should be taken into account in future long-term monitoring programs and model studies about feedbacks between thermohaline changes affecting $\mathrm{MW}$ formation and circulation and the oceanic $\mathrm{C}_{\mathrm{ANT}}$ budget.

[69] Acknowledgments. M.Á. was funded by the European Union under a Global Change I3P postdoctoral contract. F.F.P. was funded by the CICYT, VACLAN project REN2003-08193-C03-02MAR. Comments by X. A. Álvarez-Salgado were very much welcomed. We would like to give our special thanks to the Principal Scientists, scientists, and crew involved in the cruises utilized in this study. Constructive suggestions by two anonymous reviewers were appreciated.

\section{References}

Álvarez, M., H. L. Bryden, F. F. Pérez, A. F. Ríos, and G. Rosón (2002), Physical and biogeochemical fluxes and net budgets in the subpolar and temperate North Atlantic, J. Mar. Res., 60, 191-226.

Álvarez, M., A. F. Ríos, F. F. Pérez, H. L. Bryden, and G. Rosón (2003) Transports and budgets of total inorganic carbon in the subpolar and temperate North Atlantic, Global Biogeochem. Cycles, 17(1), 1002, doi:10.1029/2002GB001881.

Álvarez, M., F. F. Pérez, H. L. Bryden, and A. F. Ríos (2004), Physical and biogeochemical transports structure in the North Atlantic subpolar gyre, J. Geophys. Res., 109, C03027, doi:10.1029/2003JC002015.

Arhan, M., A. Colin de Verdière, and L. Memery (1994), The eastern boundary of the subtropical North Atlantic, J. Phys. Oceanogr., 24, $1295-1316$.

Armi, L. D., N. Hebert, N. Oakey, J. Price, P. Richardson, T. Rossby, and B. Ruddick (1988), The travels and decay of a Mediterranean salt lens, Nature, 333, 649-651.

Bacon, S. (1998), Two hydrographic sections across the boundaries of the subpolar gyre: FOUREX, RRS Discovery Cruise 230 Rep., Southampton Oceanogr. Cent., U. K.

Bacon, S., G. Reverdin, I. G. Rigor, and H. M. Snaith (2002), A freshwater jet on the east Greenland shelf, J. Geophys. Res., 107(C7), 3068, doi:10.1029/2001JC000935.

Baringer, M. O., and R. Molinari (1999), Atlantic Ocean baroclinic heat flux at $24^{\circ}$ to $26^{\circ} \mathrm{N}$, Geophys. Res. Lett., 26, 353-356.

Baringer, M. O., and J. F. Price (1997), Mixing and spreading of the Mediterranean outflow, J. Phys. Oceanogr., 27, 1654-1677.

Bogden, P. S., R. E. Davis, and R. Salmon (1993), The North Atlantic circulation: Combining simplified dynamics with hydrographic data J. Mar. Res., 51, 1-52.

Broecker, W. S., T. Takahashi, H. J. Simpson, and T. H. Peng (1979), Fate of fossil fuel carbon diozide and the global carbon budget, Science, 206, 409 .

Bryden, H. L., J. Candela, and T. H. Kinder (1994), Exchange through the Strait of Gibraltar, Prog. Oceanogr., 33, 201-248.

Bryden, H. L., M. J. Griffiths, A. M. Lavín, R. C. Millard, G. Parrilla, and W. M. Smethie (1996), Decadal changes in water mass characteristics at $24^{\circ} \mathrm{N}$ in the subtropical North Atlantic Ocean, J. Clim., 9, 3162-3186.

Candela, J. (2001), Mediterranean Water and global circulation, in Ocean Circulation and Climate: Observing and Modelling the Global Ocean, edited by G. Siedler, J. Church, and J. Gould, pp. 419-429, Elsevier, New York.

Castro, C. G., F. F. Pérez, S. E. Holley, and A. F. Ríos (1998), Chemical characterisation and modelling of water masses in the northeast Atlantic, Prog. Oceanogr., 41, 249-279.

Curry, R., M. S. McCartney, and T. M. Joyce (1998), Oceanic transport of subpolar signals to mid-depth subtropical waters, Nature, 391, 575-577.
Daniault, N., J. P. Mazé, and M. Arhan (1994), Circulation and mixing of Mediterranean Water west of the Iberian Peninsula, Deep Sea Res., Part I, $41,1685-1714$.

Dickson, B., I. Yashayaev, J. Meincke, B. Turrell, S. Dye, and J. Holfort (2002), Rapid freshening of the deep North Atlantic Ocean over the past four decades, Nature, 416, 832-836.

Dickson, R. R., W. J. Gould, T. J. Müller, and C. Maillard (1985), Estimates of the mean circulation in the deep $(>2000 \mathrm{~m})$ layer of the eastern North Atlantic, Prog. Oceanogr., 14, 103-127.

Fraga, F., C. Mouriño, and M. Manríquez (1982), Las masas de agua en la costa de Galicia: Junio-Octubre, Resut. Exped. Cien., 10, 51-77.

Fraga, F., E. D. Barton, and O. Llinás (1985), The concentration of nutrient salts in "pure" North and South Atlantic Central Waters, in Simposio Internacional Sobre las Areas de Afloramiento Más Importantes del Oeste Africano, vol. 1, pp. 25-36, Inst. de Invest. Pesqueras, Barcelona, Spain.

Fraga, F., A. F. Ríos, F. F. Pérez, and F. F. Figueiras (1998), Theoretical limits of oxygen:carbon and oxygen:nitrogen ratios during photosynthesis and mineralisation of organic matter in the sea, Sci. Mar., 62, $161-168$.

Gruber, N., J. L. Sarmiento, and T. F. Stocker (1996), An improved method for detecting anthropogenic $\mathrm{CO}_{2}$ in the oceans, Global Biogeochem. Cycles, 10, 809-837.

Harvey, J. (1981), $\theta-S$ relationship and water masses in the eastern North Atlantic, Deep Sea Res., Part A, 29, 1021-1033.

Hogg, N. G. (1987), A least-squares fit of the advective-diffusive equations to Levitus Atlas data, J. Mar. Res., 45, 347-375.

Holfort, J., K. M. Johnson, B. Schneider, G. Siedler, and D. W. R. Wallace (1998), Meridional transport of dissolved inorganic carbon in the South Atlantic Ocean, Global Biogeochem. Cycles, 12, 479-499.

Iorga, M. C., and M. S. Lozier (1999a), Signatures of the Mediterranean outflow from a North Atlantic climatology: 1. Salinity and density fields, J. Geophys. Res., 104, 25,985-26,009.

Iorga, M. C., and M. S. Lozier (1999b), Signatures of the Mediterranean outflow from a North Atlantic climatology: 2. Diagnostic velocity fields, J. Geophys. Res., 104, 26,011-26,029.

Josey, S., E. C. Kent, and P. K. Taylor (1998), The Southampton Oceanography Centre (SOC) ocean-atmosphere, heat, momentum and freshwater flux atlas, Rep. 6, 30 pp., Southampton Oceanogr. Cent., U. K.

Karstensen, J., and M. Tomczak (1998), Age determination of mixed water masses using CFC and oxygen data, J. Geophys. Res., 103, 18,59918,610 .

Käse, R. H., J. F. Price, P. L. Richardson, and W. Zenk (1986), A quasisynoptic survey of the thermocline circulation and water masses distribution within the Canary Basin, J. Geophys. Res., 91, 9739-9748.

Käse, R. H., A. Beckmann, and H.-H. Hinrichsen (1989), Observational evidence of salt lens formation in the Iberian Basin, J. Geophys. Res., 94, 4905-4912.

Klein, B., and G. Siedler (1989), On the origin of the Azores Current, J. Geophys. Res., 94, 6159-6168.

Krauss, W., and J. Meincke (1982), Drifting buoy trajectories in the North Atlantic Current, Nature, 296, 737-740.

Lavín, A. (1999), Fluxes, trends and decadal changes in the subtropical North Atlantic, Ph.D. thesis, 222 pp., Univ. of Santander, Colombia.

Macdonald, A. M., M. O. Baringer, R. Wanninkhof, K. Lee, and D. W. R. Wallace (2003), A 1998-1992 comparison of inorganic carbon and its transport across $24.5^{\circ} \mathrm{N}$ in the Atlantic, Deep Sea Res., Part II, 50, $3041-$ 3064

Mantyla, A. W. (1994), The treatment of inconsistencies in Atlantic deep water salinity data, Deep Sea Res., Part I, 41, 1387-1405.

Mazé, J. P., M. Arhan, and H. Mercier (1997), Volume budget of the eastern boundary layer off the Iberian Peninsula, Deep Sea Res., Part I, 44, $1543-1574$

McCartney, M. S. (1977), Subantarctic mode water in A Voyage of Discovery: George Deacon 70th Anniversary Volume, Deep Sea Res., 24, suppl., $103-119$.

McCartney, M. S. (1982), The subtropical recirculation of mode waters, J. Mar. Res., 40, 427-464.

McCartney, M. S., and C. Mauritzen (2001), On the origin of the warm inflow to the Nordic Seas, Prog. Oceanogr., 51, 125-214.

McCartney, M. S., S. L. Bennett, and M. E. Woodgate-Jones (1991), Eastward flow through the Mid-Atlantic Ridge at $11^{\circ} \mathrm{N}$ and its influence on the abyss of the eastern basin, J. Phys. Oceanogr., 14, 922-935.

McNeil, B. I., B. Tilbrook, and R. J. Matear (2001), Accumulation and uptake of anthropogenic $\mathrm{CO}_{2}$ in the Southern Ocean, south of Australia between 1968 and 1996, J. Geophys. Res., 106, 31,431-31,445.

Paillet, J., and H. Mercier (1996), An inverse model of the eastern North Atlantic general circulation and thermocline ventilation, Deep Sea Res., Part I, 44, 1293-1328. 
Peltola, E., et al. (2001), Chemical and hydrographic measurements on a Climate and Global Change Cruise along $24^{\circ} \mathrm{N}$ in the Atlantic Ocean WOCE Section A5R (repeat) during January-February 1998, Data Rep. OAR AOML-41, 199 pp., NOAA, Silver Spring, Md.

Pérez, F. F., A. F. Ríos, C. G. Castro, and F. Fraga (1998), Mixing analysis of nutrients, oxygen and dissolved inorganic carbon in the upper and middle North Atlantic ocean east of the Azores, J. Mar. Syst., 16, 219-233.

Pérez, F. F., L. Mintrop, O. Llinás, M. Glez-Dávila, C. G. Castro, M. Alvarez, A. Koertzinger, M. Santana-Casiano, M. J. Rueda, and A. F. Ríos (2001), Mixing analysis of nutrients, oxygen and inorganic carbon in the Canary Islands region, J. Mar. Syst., 28, 183-201.

Pérez, F. F., M. Álvarez, and A. F. Ríos (2002), Improvements on the backcalculation technique for estimating anthropogenic $\mathrm{CO}_{2}$, Deep Sea Res., Part I, 49, 859-875.

Pickart, R. S., and D. J. Torres (2002), Hydrography of the Labrador Sea during active convection, Deep Sea Res., Part I, 32, 428-457.

Pollard, R. T., and S. Pu (1985), Structure and circulation of the upper Atlantic Ocean northeast of the Azores, Prog. Oceanogr., 14, 443-462.

Pollard, R. T., M. J. Griffiths, S. Cunningham, J. F. Read, F. F. Pérez, and A. F. Ríos (1996), Vivaldi 1991-A study of the formation, circulation and ventilation of Eastern North Atlantic Central Water, Prog. Oceanogr. 37, $167-192$.

Poole, R., and M. Tomczak (1999), Optimum multiparameter analysis of the water mass structure in the Atlantic Ocean thermocline, Deep Sea Res., Part I, 46, 1895-1921.

Potter, R. A., and M. S. Lozier (2004), On the warming and salinification of the Mediterranean outflow waters in the North Atlantic, Geophys. Res. Lett., 31, L01202, doi:10.1029/2003GL018161.

Read, J. F., and W. J. Gould (1992), Cooling and freshening of the subpolar North Atlantic ocean since the 1960s, Nature, 360, 55-57.

Reid, J. L. (1979), On the contribution of the Mediterranean Sea outflow to the Norwegian-Greenland Sea, Deep Sea Res., Part A, 26, 1199-1223.

Reid, J. L. (1994), On the total geostrophic circulation of the North Atlantic ocean: Flow, patterns, tracers and transports, Prog. Oceanogr., 33, 1-92.

Rhein, M., and H. H. Hinrichsen (1993), Modification of Mediterranean water in the Gulf of Cadiz, studied with hydrographic, nutrient and chlorofluoromethane data, Deep Sea Res., Part I, 40, 267-291.

Rhein, M., J. Fischer, W. M. Smethie, D. Smythe-Wright, R. F. Weiss, C. Mertens, D.-H. Min, U. Fleischmann, and A. Putzka (2002), Labrador Sea Water: Pathways, CFC inventory and formation rates, J. Phys. Oceanogr., 32, 648-665.

Ríos, A. F., F. F. Pérez, and F. Fraga (1992), Water masses in the upper and middle North Atlantic Ocean east of the Azores, Deep Sea Res., Part A, $39,645-658$.

Ríos, A. F., F. F. Pérez, and F. Fraga (2001), Long-term (1977-1997) measurements of $\mathrm{CO}_{2}$ in the eastern North Atlantic: Evaluation of anthropogenic input, Deep Sea Res., Part II, 48, 2227-2239.

Roemmich, D., and C. Wunsch (1984), Apparent changes in the climatic state of the deep North Atlantic Ocean, Nature, 307, 447-450.

Rosón, G., A. F. Ríos, F. F. Pérez, A. Lavín, and H. L. Bryden (2003), Carbon distribution, fluxes, and budgets in the subtropical North Atlantic Ocean $\left(24.5^{\circ} \mathrm{N}\right)$, J. Geophys. Res., 108(C5), 3144, doi:10.1029/ 1999JC000047.

Sabine, C. L., et al. (2004), The oceanic sink for anthropogenic $\mathrm{CO}_{2}$, Science, $305,367-371$
Saunders, P. M. (1986), The accuracy of measurements of salinity, oxygen and temperature in the deep ocean, J. Phys. Oceanogr., 16, 189-195.

Saunders, P. M. (1987), Flow through Discovery gap, Astrophys. J. Phys. Oceanogr., 17, 631-643.

Schmitt, R. W., P. S. Bogden, and C. E. Dorman (1989), Evaporation minus precipitation and density fluxes for the North Atlantic, J. Phys. Oceanogr., 19, 1208-1221.

Siedler, G., A. Kuhl, and W. Zenk (1987), The Madeira Mode Water, J. Phys. Oceanogr., 17, 1561-1970.

Slater, D. R. (2003), The transport of Mediterranean Water in the North Atlantic Ocean, Ph.D. thesis, 155 pp., Univ. of Southampton, U. K.

Smythe-Wright, D. (1999), A Chemical and Hydrographic Atlantic Ocean Survey: CHAOS, RRS Discovery Cruise 233 Rep. 24, Southampton Oceanogr. Cent., U. K.

Soler-Aristegui, I. (2002), The role of the North Atlantic water masses in the drawdown of anthropogenic $\mathrm{CO}_{2}, \mathrm{Ph} . \mathrm{D}$. thesis, 168 pp., Univ. of Southampton, U. K.

Stommel, H. M., and A. B. Arons (1960), On the abyssal circulation of the world ocean. I. Stationary planetary flow patterns on a sphere, Deep Sea Res., 6, 140-154.

Sy, A., M. Rhein, J. R. N. Lazier, K. P. Kolterman, J. Meincke, A. Putzka, and M. Bersch (1997), Surprisingly rapid spreading of newly formed intermediate water across the North Atlantic Ocean, Nature, 386, 675679

Tait, V. K., R. M. Gershey, and E. P. Jones (2000), Inorganic carbon in the Labrador Sea: Estimation of the anthropogenic component, Deep Sea Res., Part I, 47, 295-308.

Tsimplis, M., and H. L. Bryden (1999), Estimation of transport through the Strait of Gibraltar, Geophys. Res. Abstr., 1, 392.

Tsuchiya, M. (1989), Circulation of the Antarctic Intermediate Water in the North Atlantic Ocean, J. Mar. Res., 47, 747-755.

Tsuchiya, M., L. D. Talley, and M. S. McCartney (1992), An eastern Atlantic section from Iceland southward across the equator, Deep Sea Res., Part A, 39, 1885-1917.

van Aken, H. M. (2002), The hydrography of the mid-latitude Northeast Atlantic Ocean II: The intermediate water masses, Deep Sea Res., Part I, 47, 789-824.

Willenbrink, E. (1982), Wassermassenanalyse im trophischen und subtropischen Nordostatlantik, Ber. Inst. Meereskd. Kiel, 96, 72 pp.

$\mathrm{Wu}$, P., and K. Haines (1996), Modeling the dispersal of Levantine Intermediate Water and its role in Mediterranean deep water formation, J. Geophys. Res., 101, 6591-6607.

Wunsch, C. (1978), The general circulation of the North Atlantic west of $50 \mathrm{~W}$ determined from inverse methods, Rev. Geophys., 10, 251-285.

Zenk, W. (1975), On the Mediterranean outflow west of Gibraltar, Meteorol. Forschung., 16, 23-34.

M. Álvarez and F. F. Pérez, Instituto de Investigaciones Marinas, c\Eduardo Cabello, N6, E-36208 Vigo, Spain. (malvarez@iim.csic.es; fiz@iim.csic.es)

H. L. Bryden, Southampton Oceanography Centre, Empress Dock, Southampton SO14 3ZH, UK. (h.bryden@soc.soton.ac.uk)

D. R. Shoosmith, Rosenstiel School of Marine and Atmospheric Science, University of Miami, 4600 Rickenbacker Causeway, Miami, FL 331491098, USA. (dshoosmith@rsmas.miami.edu) 

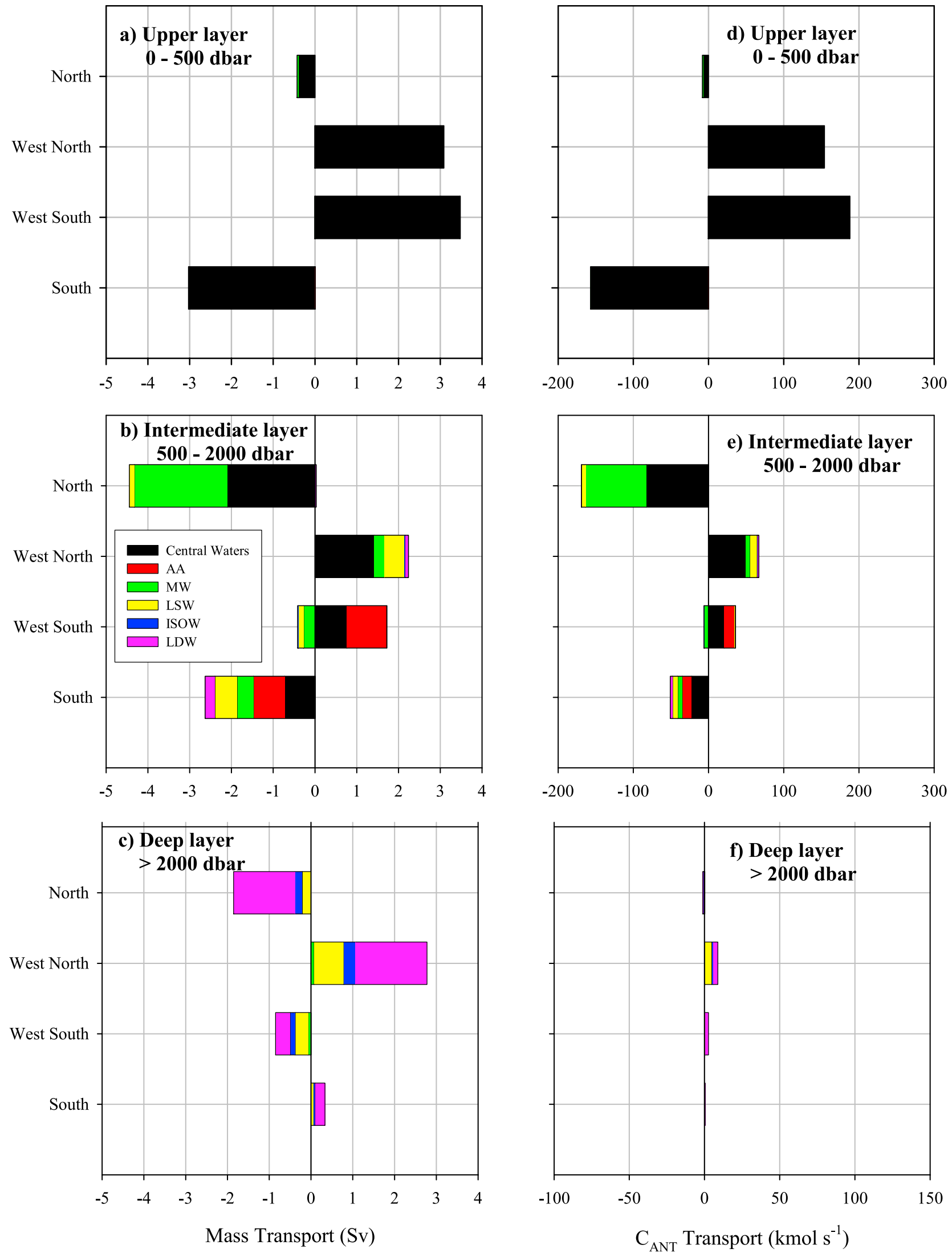

Figure 9 
Figure 9. Water mass contribution to the $(a-c)$ mass and $(d-f) C_{A N T}$ transport across the north, west north, west south, and south walls of the MedBox (see Figure 1), divided into three vertical layers shown in Figure 8a: (a, d) upper layer, less than 500 dbar; (b, e) intermediate layer, between 500 and 2000 dbar; and (c, f) deep layer, below 2000 dbar $\left(1 \mathrm{~Sv}=10^{6} \mathrm{~m}^{3} \mathrm{~s}^{-1} ; \mathrm{kmol} \mathrm{s}^{-1}=1000 \mathrm{~mol} \mathrm{~s}^{-1}\right)$. Positive (negative) values indicate a transport into (out of) the MedBox. The water mass acronyms are those in Figure 7. Note the different scale in Figure 9f. 